\title{
Recycling the Franks in Twelfth-Century England: Regino of Prüm, the Monks of Durham, and the Alexandrine Schism
}

\author{
By Simon MacLean
}

In the Middle Ages, even more so than today, history writing could be an act of political engagement. In an era without formal representation, the ability to persuade audiences of particular views of the past could be a significant weapon for those seeking to gain rhetorical leverage in political disputes. Yet "useful" history could be compiled from existing works as well as written from scratch. Because of the technologies of transmission in the age before printing, texts were essentially unstable: even authoritative works were vulnerable to editing and repackaging by copyists in ways that could fundamentally alter their original meanings. Moreover, because of the organization of manuscript production, historical compilations were more likely to reflect the views of communities rather than individual authors. Modern historians have observed that the Carolingian and Anglo-Norman periods, both of which witnessed a revival of interest in the writing of new history, also saw surges in the production of historical compilations that functioned as responses to high-level political events and contributed to the formation of social identities. ${ }^{1}$

The present article explores these issues by taking as its starting point a historical compilation from twelfth-century England that contains valuable evidence

I am very grateful to the following, who were kind enough to read the article in draft and offered invaluable advice and criticism: Rob Bartlett, David Bates, John Gillingham, John Hudson, Claire MacLean, Steve Marritt, David Rollason, Jo Story, Björn Weiler, and the journal's anonymous readers. I also benefited greatly from the comments and questions of seminar audiences at St Andrews, Leeds, and London and of the "in progress" group of the St Andrews Institute of Mediaeval Studies. This article was completed during a period of research leave funded by the Leverhulme Trust.

${ }^{1}$ From a vast bibliography see, for example, Patrick J. Geary, Phantoms of Remembrance: Memory and Oblivion at the End of the First Millennium (Princeton: Princeton University Press, 1994); Christopher Norton, "History, Wisdom and Illumination," in Symeon of Durham: Historian of Durham and the North, ed. David Rollason, Studies in North-Eastern History 1 (Stamford, UK: Shaun Tyas, 1998), 61-105; Helmut Reimitz, "Ein fränkisches Geschichtsbuch aus St. Amand: Der Cvp 473," in Text, Schrift und Codex: Quellenkundliche Arbeiten aus dem Institut für Österreichische Geschichtsforschung, ed. Christoph Egger and Herwig Weigl, Mitteilungen des Instituts für Österreichische Geschichtsforschung, Ergänzungsband 35 (Vienna: Oldenbourg, 2000), 34-90; Walter Pohl, "History in Fragments: Montecassino's Politics of Memory," Early Medieval Europe 10 (2001): 34374; Helmut Reimitz, "Weg zum Königtum in historiographischen Kompendien der Karolingerzeit," in Der Dynastiewechsel von 751: Vorgeschichte, Legitimationsstrategien und Erinnerung, ed. Matthias Becher and Jörg Jarnut (Münster: Scriptorium, 2004), 283-326; Rosamond McKitterick, History and Memory in the Carolingian World (Cambridge: Cambridge University Press, 2004), esp. 50-59 and 215-16; and Constance B. Bouchard, "Episcopal Gesta and the Creation of a Useful Past in NinthCentury Auxerre,” Speculum 84 (2009): 1-35.

Speculum 87.3 (July 2012)～doi:10.1017/S0038713412003053 
for the transmission of ideas about the ninth-century past. The manuscript that houses it (Cambridge, Corpus Christi College, MS 139, to be cited as CCCC 139) is one of the most important historical compilations of the Anglo-Norman era, containing a kaleidoscopic array of texts that are vital for our understanding of northern Britain in the eleventh and twelfth centuries, many of which texts survive nowhere else. It has therefore received significant scholarly attention. But despite its fame, the overall rationale behind its collection of texts has remained elusive. By drawing attention to a text whose role in the manuscript has not hitherto received much comment-an abbreviated version of the late Carolingian Chronicle by Regino of Prüm-I aim to throw some new light on this problem and to illuminate the ways that the Frankish past was received and put to use in twelfth-century northern England. Beyond that, however, the article seeks to situate the composition of the manuscript in a contemporary political context and, in so doing, to use it as a window onto the wider issues that shaped European politics in the third quarter of the twelfth century. The argument will be that a full understanding of this compilation helps us appreciate not just how its designers-the monks of the cathedral community in Durham-thought about history but also how they perceived the actions of contemporary kings, emperors, popes, and bishops. Treated properly it can take us to the heart of political conflict in Anglo-Norman England, revealing a distinctive regional perspective on international events shaped by the disputed pontificate of Alexander III. Moreover, it can show us how the colossal figure of Charlemagne, who loomed over the twelfth-century historical imagination, could be appropriated and pressed into the service of urgently contemporary causes. In order to draw out these implications about the meshing of past and present, we will begin with the details of the manuscript itself.

\section{Cambridge, Corpus Christi College, MS 139}

CCCC 139 is a large and justly famous manuscript, illustrative of northern English historical consciousness in the middle of the twelfth century and the chief or unique witness to a number of crucial narrative texts, including the Historia regum (History of the Kings) attributed to Symeon of Durham; its continuation by John of Hexham; and the so-called Nennian recension of the Historia Brittonum (History of the Britons). ${ }^{2}$ The structure and provenance of the codex (which was bequeathed to the college by Matthew Parker in 1575) have been extensively analyzed. All recent discussion builds on the fundamental studies by Peter Hunter Blair and Derek Baker, who showed that the manuscript, which was written by multiple scribes in the mid- to late twelfth century, was not just a compilation of texts but indeed a compilation of compilations. ${ }^{3}$ On the basis of a

\footnotetext{
${ }^{2}$ The manuscript itself, together with a detailed description and bibliography, can now be viewed online at http://parkerweb.stanford.edu/parker/actions/page.do?forward=home. The full list of contents is given in the Appendix, p. 681. All numbered texts refer to this table.

${ }^{3}$ Peter Hunter Blair, "Some Observations on the 'Historia regum' Attributed to Symeon of Durham," in Celt and Saxon: Studies in the Early British Border, ed. Nora Chadwick (Cambridge: Cambridge University Press, 1963), 63-118; Derek Baker, "Scissors and Paste: Corpus Christi, Cambridge, MS
}

Speculum 87.3 (July 2012) 
variety of codicological and paleographical observations, Baker identified four coherent groups of texts, which probably existed as independent booklets for a short time before being bound together into their present form. The largest of these booklets-which I will hereafter refer to as "the main booklet" or, simply, "the booklet"-comprises texts 2 to 13, Regino of Prüm's Chronicle to Aelred of Rievaulx's Miracle of the Nun of Watton, and thus contains most of the manuscript's major historical works. These were copied by a small group of scribes, who worked to a single template and often changed shifts mid-text, and were rubricated by a single hand. These conclusions, which have been endorsed and refined by subsequent scholarship, suggest that the main booklet was the product of a team working together on a single project, rather than the result of random copying or a miscellany reflecting the separate interests of several individuals. ${ }^{4}$ The present article is primarily concerned with the origins of this booklet rather than with the whole manuscript as it stands today.

Because of the complicated structure of the manuscript, we must think first of all about its individual booklets when trying to establish the manuscript's date. ${ }^{5}$ The palaeography indicates a date somewhere in the later twelfth century, but the texts themselves offer some more precise clues. Three such clues are to be found in our booklet: the rubric to Richard of Hexham's work (text 3) refers to him in the past tense- his date of death is not known, but he was still alive at some point in the period 1161-67; the Historia regum (text 7) contains a presenttense reference to an abbot of Whitby who died in 1175; and William of Glasgow's poem (text 11) refers to the death of Somerled in 1164. The main booklet must, therefore, have been put together no earlier than 1164 and no later than 1175 . Clues from elsewhere in the codex suggest that other parts of the manuscript most likely belong to the same chronological window: the vision of the deceased Malcolm IV of Scotland (text 23) must be dated in or after 1165 (the year of that king's death), while comparison of marginal notes in the Historia Brittonum (text 25) with copies of the same text in closely related manuscripts demonstrates that the CCCC 139 version was probably copied around $1166 .{ }^{6}$ It is likely, then, that each of the constituent booklets was created about the same time in the later 1160s and that they were bound together into the manuscript as it currently stands within one or two decades, and certainly before the end of the twelfth century.

\footnotetext{
139 Again," Studies in Church History 11 (1975): 83-123. See also the lucid discussion by Paul Hayward at http://www.lancs.ac.uk/staff/haywardp/hist422/seminars/Corpus139.htm.

${ }^{4}$ Baker, "Scissors and Paste," 84-86 and 97-98. For scholarly endorsement see, for example, Joanna Story, "Symeon as Annalist," in Symeon, ed. Rollason, 202-13, at 211-12.

${ }^{5}$ Baker, "Scissors and Paste," 94.

${ }^{6}$ For extended discussion of all these points see Baker, "Scissors and Paste," 94-98; David Dumville, "The Corpus Christi 'Nennius,", Bulletin of the Board of Celtic Studies 25 (1974): 369-80; David Dumville, “'Nennius' and the 'Historia Brittonum,'” Studia Celtica 10-11 (1975-76): 78-95; and David Dumville, "Celtic-Latin Texts in Northern England, c.1150-c.1250," Celtica 12 (1977): 1949. Blair, "Observations," 77-78, argues that a rubric added to the Historia regum can be read as indicating that the copyist was writing in September 1164, but this conclusion relies on some debatable inferences: see Baker, "Scissors and Paste," 96 n. 97.
} 
The consensus for much of the twentieth century was that the manuscript was compiled at Hexham, with which a number of its texts can be associated-not just the histories by Richard and John of Hexham but also the Historia regum, which contains interpolations relating to the history of that house. Blair challenged this assumption by arguing (on stylistic and thematic grounds) in favor of the Cistercian house of Sawley in Yorkshire, and this view seemed to be confirmed by the discovery in the manuscript of an erased Sawley ex libris in a latetwelfth-century hand. Others have contended, using arguments based on the coverage and likely origins of the constituent texts, that the manuscript may have ended up at Sawley but that it started out at another northern house, such as Fountains. ${ }^{7}$ These arguments have their merits, but each tends to overlook the composite nature of the manuscript in assuming that the clear signatures of individual houses' interests in parts of the compilation should be taken to explain the whole. Taken on its own, the booklet comprising texts 2-13 bears an unmistakable Durham imprint. Texts 5-7 all originated in Durham, while texts 2 and 4 were demonstrably copied at Durham from identifiable surviving manuscripts. ${ }^{8}$ Even the material that seemingly points toward Hexham can be made to fit comfortably in this Wearside context, since Durham's claims over that church (which was technically part of an island of York jurisdiction in the north) were being pressed and indeed formalized precisely in the middle of the 1160s. ${ }^{9}$ The booklet also contains marginal notations highlighting passages of interest to at least one contemporary reader. That the annotator(s) marked as "d.m." (dignum memoria, "worth remembering") passages in the Chronicle and Historia regum relating to Northumbrian history, and in particular to Bede, St. Cuthbert, and the monastery of Monkwearmouth-Jarrow, strengthens the case for a Durham provenance. ${ }^{10}$ As regards the manuscript as a whole, matters are less clear, though it is interesting that ours is not the only booklet with strong Durham connections: the version of the Historia Brittonum (text 25) found

\footnotetext{
${ }^{7}$ For discussion, including citation of the earlier literature, see Blair, "Observations," 70-74; H.S. Offler, "Hexham and the "Historia regum," Transactions of the Architectural and Archaeological Society of Durham and Northumberland, n.s. 2 (1970): 51-62; Baker, "Scissors and Paste," 98-105; and Dumville, "Corpus Christi 'Nennius,"” 371-72.

${ }^{8}$ B. Meehan, "Durham Twelfth-Century Manuscripts in Cistercian Houses," in Anglo-Norman Durham: 1093-1193, ed. David Rollason et al. (Woodbridge: Boydell, 1994), 439-49, at 440-42; Norton, "History, Wisdom and Illumination," 87-88 and 101-2; Story, "Symeon as Annalist," 20913; Bernard Meehan, "Notes on the Preliminary Texts and Continuations to Symeon of Durham's 'Libellus de exordio,'” in Symeon, ed. Rollason, 128-39, at 129 and 136-37; Joanna Story, "Frankish Annals in Anglo-Norman Durham," in Wilhelm Levison (1876-1947): Ein jüdisches Forscherleben zwischen wissenschaftlicher Anerkennung und politischem Exil, ed. M. Becher and Y. Hen (Siegburg: Franz Schmitt, 2010), 145-60.

${ }^{9}$ Geoffrey V. Scammell, Hugh du Puiset, Bishop of Durham (Cambridge: Cambridge University Press, 1956), 170-71; Norton, "History, Wisdom and Illumination," 100. Note also that Aelred of Rievaulx and Richard of Hexham were friends of the Durham monks, having adjudicated in their favor during a dispute in the 1140s: Everett Crosby, Bishop and Chapter in Twelfth-Century England: A Study of the Mensa episcopalis, Cambridge Studies in Medieval Life and Thought, 4th ser. 23 (Cambridge: Cambridge University Press, 1994), 145.

${ }^{10}$ For example, fols. 26v, 55v, 56r, and 62r. These "d.m." annotations (which are not restricted to Northumbrian passages) were characteristic of some twelfth-century scriptoria: Teresa Webber, Scribes and Scholars at Salisbury Cathedral, c.1075-c.1125 (Oxford: Clarendon Press, 1992), 132-34.
}

Speculum 87.3 (July 2012) 
in CCCC 139 was used to update versions of the same text in at least two other Durham manuscripts, making it probable that it, too, originated in the cathedral. ${ }^{11}$

The presumptions underlying the argument in this article are therefore that the booklet comprising texts 2 to 13 was compiled in the later 1160 s in the cathedral community at Durham by a team of scribes working to a deliberate plan, and that the texts that appear in edited form (Regino of Prüm and John of Hexham) were so edited for the purposes of this plan. ${ }^{12}$ These assumptions remain hypothetical to a degree, but they reflect a consensus among those who have studied the manuscript since the 1970s. One of the aims of this article is to explore the implications of these presumptions. However, it must be stressed that the argument that follows rests above all on observations about the contents and sequencing of the group of major historical texts at the heart of the manuscript, rather than on a particular view of how the codex was constructed. It does not, therefore, require full acceptance in every detail of Baker's interpretation of the codicology nor of any one of the variations suggested by other scholars who have described the manuscript.

\section{The Epitome of Regino's ChronicLE}

Scholarly interest in the contents of the Corpus manuscript has been understandably dominated by the big-name texts it contains, in particular its fascinating versions of the Historia regum and the Historia Brittonum. The shorter and fragmented texts have not aroused much excitement. This is hardly surprising in the case of Regino of Prüm's Chronicle, which at first glance seems curiously out of place among the manuscript's English and Scottish material. ${ }^{13}$ Regino (d.915) was the last major historian of the Carolingian Empire and wrote his Chronicle in 908 after losing his position as abbot of the major monastery of Prüm. The text is written in two books, the first a cut-and-paste compilation running from the birth of Christ to the death of the Frankish mayor Charles Martel in 741; the second, a mostly independent account of events from that point until 906. Superficially the Chronicle resembles a world chronicle or universal history and has often been categorized as such, but its central theme is expressed in its compelling and coherent narrative about the rise and fall of the Franks and their greatest rulers, the Carolingians. ${ }^{14}$

\footnotetext{
${ }^{11}$ Dumville, “Corpus Christi 'Nennius,'” esp. 372-73. Dumville hypothesized that CCCC 139 was sent as an "interlibrary loan" item to Durham from Sawley for this purpose, but more recent scholarship has established that all of the manuscripts involved were made in Durham: Norton, "History, Wisdom and Illumination," 71 and n. 20; Story, "Symeon as Annalist," 212.

12 This is virtually certain for the latter, at least, since one of the texts added to it was not written until 1164 at the earliest. The origins of the edited Regino are discussed in the next section.

${ }^{13}$ Regino of Prüm, Chronicle, ed. Friedrich Kurze, Reginonis abbatis Prumiensis Chronicon cum continuatione Treverensi, MGH SS rer. Germ. 50 (Hannover: Hahn, 1890). For a translation see Simon MacLean, History and Politics in Late Carolingian and Ottonian Europe: The Chronicle of Regino of Prüm and Adalbert of Magdeburg (Manchester: Manchester University Press, 2009), 61-231.

${ }^{14}$ On Regino's work and career see now Stuart Airlie, "Sad Stories of the Deaths of Kings': Narrative Patterns and Structures of Authority in Regino of Prüm's 'Chronicon,'” in Narrative and
} 
Given that it survives in around thirty manuscripts, many of them complete and relatively early, the excerpted version of the Chronicle that appears in CCCC 139 has not excited much comment from scholars interested in the transmission of Carolingian histories. ${ }^{15}$ Equally, the epitome has held limited interest for historians of England because Regino's work was barely known there in the Middle Ages: the CCCC 139 extract is one of only two copies of the work known from medieval England. The other copy was also at Durham, showing that English affection for the work was not only short-lived but also localized. Nonetheless, we should resist the temptation to dismiss the lesser texts housed in CCCC 139 as mere miscellanies and be wary of assuming that their inclusion was "random" or "arbitrary." 16 Indeed, it might well be argued that such cut-and-paste jobs offer us the best opportunity to reconstruct the mentality and intentions of medieval compilers: by using the original text as a control, the criteria of selection can perhaps be discerned and a sense of the editorial thought process recovered.

Before analyzing the Corpus Regino in this way, it is worth emphasizing that there are prima facie reasons for believing that the work of excerption was a conscious process, and that the compilers sifted the material carefully in order to carve out a new narrative. Most importantly, the manuscript that served as the source for the abridged Corpus version can be identified as Durham, Dean and Chapter Library, MS C IV 15. This manuscript was probably imported to Durham from a Continental center after c.1130. ${ }^{17}$ The full copy of the Chronicle found in this book is marked up with marginal notations that correspond to the Corpus excerpts, telling the scribes where to start copying and where to stop..$^{18}$ As well as establishing the link between the two manuscripts, the annotations indicate that the epitomists were very familiar with the text of the Chronicle and applied predefined criteria in selecting sections to be copied. This impression is confirmed by the fact that some of the material copied is itself carefully chopped and then seamlessly restitched. Sometimes this was done for no other reason than to assist clarity. To give just one example, Regino's entry for 808 is plundered for a single line at the beginning (about Charlemagne's movement between Nijmegen and Aachen), then a larger chunk from the middle; the only purpose of the initial line was seemingly to clarify a throwaway reference in the main

History in the Early Medieval West, ed. Elizabeth M. Tyler and Ross Balzaretti, Studies in the Early Middle Ages 16 (Turnhout: Brepols, 2006), 105-31; MacLean, History and Politics, 8-53; and Simon MacLean, "Insinuation, Censorship and the Struggle for Late Carolingian Lotharingia in Regino of Prüm’s Chronicle," English Historical Review 124 (2009): 1-28.

${ }^{15}$ Wolf-Rüdiger Schleidgen, Die Überlieferungsgeschichte der Chronik des Regino von Prüm, Quellen und Abhandlungen zur mittelrheinischen Kirchengeschichte 31 (Mainz: Selbstverlag der Gesellschaft für mittelrheinische Kirchengeschichte, 1977), is the only sustained study of the transmission of Regino, with discussion of CCCC 139 at 40-41.

${ }^{16}$ Baker, "Scissors and Paste," 84, 97, and 99.

${ }^{17}$ Story, "Frankish Annals in Durham," provides convincing arguments for this dating.

${ }^{18}$ A.J. Piper, "The Historical Interests of the Monks of Durham," in Symeon, ed. Rollason, 30132, at 328. Piper credits this observation to M.R. Foster. For a description of the manuscript see Schleidgen, Überlieferungsgeschichte, 38-40.

Speculum 87.3 (July 2012) 
section to the fact that the emperor was "still" at Nijmegen. Despite its failure to achieve long-term popularity, there is some evidence that in the mid-1160swhen the epitome was presumably composed-Regino's history carried some authority. This is reflected in the heading given to the text in CCCC 139: "The chronicle of the abbot of the monastery of Prüm, where the emperor Lothar converted to the monastic life." ${ }^{19}$ The adoption of monastic lifestyles by secular rulers was a central interest of both Regino and, as we shall see, the Durham epitomists, but Lothar's retirement to Prüm (which took place in 855) was not included in the excerpted Corpus version. Clearly, the twelfth-century rubricator knew the full text sufficiently well to encapsulate its essence with reference to an event not mentioned in the version he was rubricating. This surely presumes a similarly knowledgeable audience and underlines the prominence of Regino's Chronicle in the historical consciousness of the Durham cathedral community in the middle decades of the twelfth century.

We are entitled to assume, then, that the sections of the Chronicle selected by the epitomizers for copying into the Corpus booklet were chosen with care and precision. ${ }^{20}$ The whole of book 1 (Regino's own cut-and-paste version of history from the birth of Christ to the death of Charles Martel in 741) was included, but book 2 was subject to aggressive editing. For the period from 741 until Charlemagne's death in early 814, Regino repeated, virtually verbatim, a version of the Royal Frankish Annals, with only two significant additions. These additions, depicting the abdication of the Frankish mayor Carloman in 745-46 and the blessing of King Pippin by Pope Stephen in 753, were chosen to open the second book of the Corpus epitome. The epitome then jumps to a selection of material surrounding Charlemagne's invasion of Italy and his imperial coronation, utilizing material from the $776,799,801,803$, and 804 entries, before moving to a selective account of the emperor's dealings with Britain and Ireland, which incorporated excerpts from the $807,808,809,812$, and 813 annals. After Charlemagne's death the recycling of Regino's work becomes even more selective, comprising elements of the following entries: 842 (Treaty of Verdun), 868 (an obituary of Pope Nicholas I and an anecdote about the Bulgarian king Boris), 870 (Treaty of Meersen), 873 (a plague of locusts), 874 (an obituary of Emperor Louis II), 876 (an obituary of King Louis the German), 883 (an obituary of King Louis III of West Francia), 887-89 (the Viking siege of Paris, the deposition and death of Emperor Charles III the Fat, an account of the origins of the Hungarians), 896 (the taking of Rome by Emperor Arnulf), and, finally, 901 (the Hungarian invasion of Italy and the death of Bishop Liutward of Vercelli). ${ }^{21}$

\footnotetext{
${ }^{19}$ Fol. 17r: "Incipit cronica abbatis prumiensis monasterii ubi lotharius imperator ad conversionem venit."

${ }^{20}$ The narrow chronological gap and close textual association between the Corpus epitome and its Durham source, as well as the absence of other Regino manuscripts, make it likely that the epitome was created specifically for the booklet.

${ }^{21}$ The dates given here are those in the original by Regino, who himself placed some of these events in the wrong years. The Durham scribes miscopied some of them, usually producing errors of a year or two, and in one case (1002 for 901) a whole century.
} 
This highly selective treatment of Regino's text decontextualizes the original narrative and denudes it of its strongly dynastic message, a moral-political story about the rise and fall of the Carolingian dynasty. ${ }^{22}$ This departure must be seen as a conscious choice, since the dynastic interpretation was clearly signaled in the structure and layout of the community's earlier copy of the complete Chronicle, which was accompanied by the triumphally pro-Carolingian Earlier Metz Annals. ${ }^{23}$ The Durham remix of Regino, which did not even include the accession of the first Carolingian king, Pippin, in 751, had a different story to tell. The meaning of this story need not be boiled down to a single purpose: historical texts were multifaceted ideological and moral resources, and history was perceived as having an intrinsic value for the lessons it could teach about the exercise of power and God's intervention in the world. ${ }^{24}$ Nonetheless, certain themes emerge from the excerpts that must have had distinct contemporary resonances. Some of these are general. Anne Lawrence-Mathers has argued that the whole manuscript reflects a northern historical sensibility that implicitly stressed the importance of placing English events in the context of universal history (a genre that usually included material from the Bible and from late-antique historians) in conscious opposition to the contemporary obsession with Arthuriana sparked off by Geoffrey of Monmouth's History of the Kings of Britain (c.1136).25 This interest was especially reflected in the main booklet's first few texts, including book 1 of the Chronicle. We can also see some of the Regino extracts as attempts to satisfy the specific historical interests of the Durham monks. Some of the eighth-century entries, for example the long anecdote told by Regino about the pious Carolingian mayor Carloman, fleshed out the much sketchier versions of the same events recounted in the early twelfth-century Annals of Lindisfarne and Durham, while the copyists' sustained interest in Charles the Fat and the disintegration of the Carolingian Empire in 888 may have been triggered by the allusions to these events found in the Historia regum and in versions of the Anglo-Saxon Chronicle that may have been known at Durham. ${ }^{26}$ Other vignettes

\footnotetext{
${ }^{22}$ Airlie, "Narrative Patterns."

${ }^{23}$ On these features of the earlier manuscript see Story, "Frankish Annals in Durham."

${ }^{24}$ See, for example, Karl Ferdinand Werner, "Dieu, les rois et l'histoire," in La France de l'an mil, ed. Robert Delort (Paris: Editions du Seuil, 1990), 264-81; Yitzhak Hen and Matthew Innes, eds., The Uses of the Past in the Early Middle Ages (Cambridge: Cambridge University Press, 2000); and Walter Goffart, "Bede's Vera lex historiae Explained," Anglo-Saxon England 34 (2005): 111-16.

${ }^{25}$ Anne Lawrence-Mathers, "William of Newburgh and the Northumbrian Construction of English History," Journal of Medieval History 33 (2007): 339-57, esp. 350. On the twelfth-century fascination with universal history see Richard W. Southern, "Aspects of the European Tradition of Historical Writing, 2: Hugh of St Victor and the Idea of Historical Development," in History and Historians: Selected Papers of R.W. Southern, ed. Robert Bartlett (Malden, MA: Blackwell, 2004), 30-47.

${ }^{26}$ Wilhelm Levison, "Die Annales 'Lindisfarnenses et Dunelmenses,'” Deutsches Archiv für Erforschung des Mittelalters 17 (1961): 447-506; Story, "Symeon as Annalist," 207-9; Joanna Story, "The Frankish Annals of Lindisfarne and Kent," Anglo-Saxon England 34 (2005): 59-109. The Historia regum may draw on a copy of the E text of the Anglo-Saxon Chronicle: Hilary S. Offler, "Medieval Historians of Durham," in Hilary S. Offler, North of the Tees: Studies in Medieval British History (Aldershot: Variorum, 1996), no. 1, 9 and 21; Piper, "Historical Interests," 321; Anne Lawrence-Mathers, Manuscripts in Northumbria in the 11th and 12th Centuries (Woodbridge: D.S. Brewer, 2003), 157.
}

Speculum 87.3 (July 2012) 
supplemented gaps in the monks' knowledge, most clearly Regino's accounts of the exile and return of the Northumbrian king Eardwulf in 808-9 and of Viking raids on Ireland in 812, whose local color helped bridge a chronological chasm between the years 802 and 849 in the Historia regum. ${ }^{27}$ Still others, like the account of the remarkable locust infestation of 873 , may have been included for their intrinsic interest-though that event, too, had been recorded in contemporary insular annals. ${ }^{28}$

However, it can be argued that these intertextual echoes responded at the same time to events in the wider political environment in and around Durham. Almost all of the material selected from Regino's second book seems to relate to one or the other of two coherent themes. The first is kingship itself. The Chronicle contained several vignettes about good rulership, often couched as anecdotes or obituaries, and it is striking that the Corpus remix includes almost all of them. A lot of these stories emphasize standard virtues of kingship. Louis the German was hard, fair, and incorruptible; Louis II of Italy pious, generous, and God-fearing; and the Breton $d u x$ Wrhwant brave and righteous. More striking is the fact that a number of these anecdotes draw on a specifically monastic sensibility and cast their royal protagonists in a Benedictine mold. Thus the story of Charles the Fat's patient endurance of the great hardships occasioned by his deposition in 88788 , lingered over by Regino as a monkish example of kingly piety, is included by the compilers-though significantly they omitted the Chronicle's famous account of the dynastic ramifications. ${ }^{29}$ The epitomists also liked the story of Boris, the first Christian king of the Bulgarians, reported by Regino under the year 868 . Once baptized, Boris began to live a double life, dressing in royal finery by day but by night clothing himself in a sack and lying prostrate on the stone floor of a church. In the end he abdicated and entered a monastery, emerging only briefly to blind and imprison his immoral son before returning to spend "the rest of his earthly life in holy monastic conduct." 30 The clearest example of all is Regino's anecdote about the Carolingian "king" (actually mayor of the palace) Carloman in 745-46, adopted by the Durham epitomists as the opening entry in their abbreviated version of book 2. At some length Regino relates how Carloman, the brother of Pippin and uncle of Charlemagne, abdicated his secular position and traveled to Italy, where he first built a monastery at Monte Soracte before enrolling anonymously as a novice in the great house of Monte Cassino, the very home of the Benedictine rule. There, we are told, he lived a blameless life among the brothers and suffered mistreatment at the hands of the cook, patiently refusing to retaliate or to make known his true identity. Only after matters had

\footnotetext{
${ }^{27}$ As Story, "Frankish Annals in Durham," points out, it is likely that Symeon would have included the Eardwulf story in his world chronicle and his Historia regum (texts 4 and 7 in CCCC 139) had Regino's work or the Metz annals been available to him. See further Joanna Story, Carolingian Connections: England and Francia c.750-870 (Aldershot: Ashgate, 2003), 145-62. The Eardwulf story in the Corpus epitome is stitched together from different sections of the Chronicle, which underlines the point that the epitome was carefully tailored to specific interests.

${ }^{28}$ David Thornton, "Locusts in Ireland? A Problem in the Welsh and Frankish Annals," Cambrian Medieval Celtic Studies 31 (1996): 37-53.

${ }^{29}$ Regino, Chronicle, 125-29, s.aa. 887 and 888.

${ }^{30}$ Regino, Chronicle, 95-96, s.a. 868.
} 
escalated into a disciplinary procedure was his identity inadvertently revealed, causing much trembling among the brethren and leading to much better treatment for Carloman. ${ }^{31}$ The moral of this story was clear, and it echoed the messages of the others: Carloman's inherent royalty was enhanced rather than effaced by his ostentatious submission to the privations of monastic life. ${ }^{32}$ Indeed, the text itself paraphrases sections of the Benedictine rule and illuminates its strictures, so that it also serves as a didactic parable, an object lesson in correct observance. $^{33}$

It was as descriptions of rulers exhibiting Benedictine-style discipline that these stories must have struck the Durham compilers. The cathedral convent at Durham had been transformed from a house of canons into a Benedictine community in 1083 (an unusual shift in European terms, though relatively familiar in England), and this event loomed large in the collective consciousness of its members. Durham historians became accustomed to cladding their heroes in monks' clothing. Symeon's house history, Libellus de exordio atque procursu istius hoc est Dunhelmensis ecclesie (Tract on the Origins and Progress of This the Church of Durham), written between 1104 and 1107, depicted William of Saint-Calais, the late-eleventh-century bishop remembered as the father figure of the reform, as an exemplary monastic figure, "moderate in eating and drinking ... catholic in his faith and chaste in his body." 34 The ultimate exemplar here was St. Cuthbert, patron saint of the community and paragon of the monastic-episcopal virtues it prized..$^{35}$ The epitomists' quarrying of vignettes on this theme from Regino's Chronicle therefore reflected the core values of the cathedral community and shows us the yardsticks against which its members were inclined to measure secular as well as religious leaders. Little wonder, then, that at least one of the monks (the rubricator) saw the defining feature of Regino's Chronicle as being its association with another monastery to which an emperor-Lothar I-had retired. ${ }^{36}$

The second consistent theme in the epitome's depiction of rulerly conduct is the relationship between kings/emperors and popes. Book 1 of the Chronicle is full of material on this topic-indeed, this is one of the main themes of Regino's original, which characterizes Rome as an apostolic city rather than a center of secular power and praises rulers for defending the Church rather than wielding imperial authority. ${ }^{37}$ In the Chronicle, as already mentioned, book 2 narrows into a story about the rise and fall of the Carolingian dynasty. In the epitomized

\footnotetext{
${ }^{31}$ Regino, Chronicle, 41-43, s.aa. 745-46.

${ }^{32}$ MacLean, History and Politics, 32-33.

${ }^{33}$ Arno Borst, Lebensformen im Mittelalter (Frankfurt: Propyläen, 1973), 528-31.

${ }^{34}$ Symeon of Durham, Libellus de exordio atque procursu istius hoc est Dunhelmensis ecclesie 4.1, ed. and trans. David Rollason (Oxford: Oxford University Press, 2000), 222-25; William Aird, St Cuthbert and the Normans: The Church of Durham, 1071-1153 (Woodbridge: Boydell, 1998), 104-6. This text survives in several manuscripts, one of them closely related to CCCC 139, and there is no doubt that it remained influential in later twelfth-century Durham: Norton, "History, Wisdom and Illumination"; Rollason, introduction to Symeon, Libellus, xxiv-xxvii.

${ }^{35}$ Symeon, Libellus 1.3, 1.9, and 4.8, pp. 24-29, 44-49, and 246-47 (the last alludes to the Benedictine rule).

${ }^{36}$ See above, p. 655.

${ }^{37}$ MacLean, History and Politics, 23-28.
}

Speculum 87.3 (July 2012) 
version, however, most of the detailed context informing this narrative is cut away, and the themes of papal agency and royal humility are made to stand out even more prominently. The tone is set unmistakably by the choice of sequel to the Carloman story. Omitting the entries for 749 and 750, which relate Pippin's election as the first Carolingian king "according to Frankish custom," the epitomists skipped to $753 .{ }^{38}$ Here we are told that Pippin journeyed to Rome "by apostolic invitation, seeking to do justice for the apostle Peter" against the raids of the Lombards. Pope Stephen traveled back to Saint-Denis, where he experienced a vision involving SS. Peter, Paul, and Denis and anointed Pippin and his family as kings. This was done explicitly on the authority of St. Peter, and the text asserts that the Franks were bound not to raise any other family to kingship. In the narrative arc sketched out by Regino, this anecdote conveyed a primarily dynastic message, confirming the Carolingians as defenders of the Church and rightful rulers and setting the stage for the subsequent account of their rise, decline, and fall. ${ }^{39}$ In the view of the epitomists, to judge from what follows, the story's assertion of the primary role of Petrine authority (rather than "Frankish custom") in the making of the Carolingians was what recommended it.

The collection then skips to Charlemagne subduing Italy in 776 and from there, omitting an abundance of material concerning victories over neighboring peoples, jumps straight to the events surrounding Charles's imperial coronation in Rome (Christmas Day, 800). The version given of these events is extremely selective: from the 799 entry we get the opening lines describing the attack on Pope Leo III during the greater litany and his escape into the hands of Charlemagne's representatives; and from the 801 entry, a terse account of Leo crowning the king before the shrine of St. Peter followed by the trial and condemnation of the pope's enemies (with Leo persuading the emperor to temper his harsh sentence)..$^{40}$ The significance of this selection resides in what it leaves out: Leo sending Charlemagne the keys to the tomb of St. Peter; the king's stately progress to Rome and his reception of numerous gifts signaling his imperial status; and the pope showing the king the respect due to an old-style emperor by coming twelve miles outside the city to meet him. The original text of the Royal Frankish Annals used by Regino had been intended, not surprisingly, to portray Charlemagne and the Franks in the driving seat, riding to the rescue of a weak and even pathetic Leo and receiving the due reward of imperial status. By filleting out most of the detail and reducing the story to two key events, the excerpted version restored agency to the pope, giving parity to the two main actors and indeed placing the emperor at the pope's service. Their comradeship was underlined by the next selection, a short passage from the middle of Regino's 804 entry that recounted how Leo came to visit Charles, after rumors spread of the blood of Christ being found in Mantua, and stayed with him for eight days. ${ }^{41}$ The inclusion of parts of the 807,808 , and 809 entries, at the center of which sat the story of the deposition and restoration of King Eardwulf of Northumbria, must have responded to local

\footnotetext{
${ }^{38}$ Regino, Chronicle, 44-45, s.a. 753.

${ }^{39}$ Airlie, "Narrative Patterns."

${ }^{40}$ Regino, Chronicle, 60-63, s.aa. 799 and 801.

${ }^{41}$ Regino, Chronicle, 65, s.a. 804.
} 
interest and the fact that the monks' other sources gave no more than tantalizing details about the incident. ${ }^{42}$ Yet here, too, there were familiar overtones, for the king's restoration was accomplished, we are told, by the joint actions of papal and imperial envoys. The text then jumps straight to Charlemagne's death (the last point at which Regino used the Royal Frankish Annals), omitting lots of material on diplomacy, war, and dynasty and pausing only to mention a failed Viking attack on Ireland. ${ }^{43}$

The remainder of Regino's second book, from 813 to 906, was subject to even more rigorous editing. The relatively coherent, albeit drastically excerpted, narrative of the era of Pippin and Charlemagne changes to a highly episodic selection of vignettes concerning the attributes and deeds of individual rulers, virtually devoid of context. Although a lot of these stress service to the Church as a primary royal quality, some dwell specifically on positive relations with popes. For example, the epitomists included a story about Arnulf of Carinthia, the last Frankish emperor, who in 896 went to Rome and "was received with great honor by Formosus, the bishop of the apostolic see, and was crowned emperor before the altar of St Peter." 44 This was accomplished with an unprecedented show of force, according to Regino, but the abbot of Prüm's implicit note of disapproval, sounded in the story's final sentence, which relates that Arnulf was then struck down with a "paralyzing illness," was left out by the epitomists. Such omissions should be seen as significant. The epitomists' various celebrations of papalimperial cooperation, such as that between Arnulf and Formosus, must be read in light of their rejection of counterexamples available in the Chronicle, such as Charles the Bald's acquisition of the imperial title by bribing Pope John VIII. ${ }^{45}$ We can be confident that the latter story was programmatically omitted from the Corpus version because it was reported in the 874 annal, which was reproduced in full by the epitomists except for the last three sentences.

Two final entries in the recycled version of book 2 confirm this impression of the epitomists' intentions. Regino recorded the Treaty of Verdun (843), by which Charlemagne's grandsons divided the empire into three kingdoms, under the year 842 , and this was the first passage selected for inclusion after the emperor's death. The epitomists were otherwise indifferent to Frankish regnal arrangements, and it seems likely that their real interest here was in the description of the portion given to the emperor Lothar I (the same Lothar mentioned by the rubricator). Among Lothar's territories was Italy, "including the town of Rome itself, which even now is venerated by all the holy church with a certain special status because of the presence of the apostles Peter and Paul, and which formerly was called the mistress of the lands of the earth because of the undefeated power of the name of Rome." 46 The very next entry in the epitome is the opening paragraph of the Chronicle's entry for 868. This is an obituary for Pope Nicholas I,

\footnotetext{
${ }^{42}$ Regino, Chronicle, 66-69, s.aa. 807-9. See above, p. 657. Most of the material in these entrieson the Vikings, for example-is left out.

${ }^{43}$ Regino, Chronicle, 72, s.a. 812.

${ }^{44}$ Regino, Chronicle, 144, s.a. 896.

${ }^{45}$ Regino, Chronicle, 110, s.a. 874.

${ }^{46}$ Regino, Chronicle, 75, s.a. 842.
}

Speculum 87.3 (July 2012) 
which characterizes him as a dominator of secular rulers and ardent defender of the Church. Interestingly, it includes a verbal echo of the 842 excerpt: "He commanded kings and tyrants and exercised authority over them as if he was the lord of the lands of the earth." ${ }^{77}$ This echo suggests that Regino had a clear sense of the distance of the past as far as the Eternal City was concerned, a sense that underlined the main theme of book 1: Rome may once have been an imperial center, but now its aura was emphatically apostolic, and therefore papal. ${ }^{48}$ For Regino, this celebration of Nicholas's virtues was an integral part of one of his central arguments: that King Lothar II, whose nemesis Nicholas was, had brought divine displeasure on the Franks by prosecuting an illegitimate divorce case during the $860 \mathrm{~s} .^{49}$ For the monks of Durham the message was decontextualized, its most direct and striking expressions starkly juxtaposed rather than carefully woven into a polemical narrative. Lothar II is nowhere to be seen. The heroic authority exercised by Pope Nicholas I, commander of kings and tyrants, becomes in the retelling a historically authorized and abstract statement of principle: the Rome of the emperors was long gone, definitively supplanted by the Rome of the apostolic popes.

The epitome of the Chronicle is therefore a patchwork that articulates a number of primary themes: the virtues of Benedictine-flavored royal humility; the need for kings to protect the Church; and the fundamental rightness of rulers' submitting to, or at least cooperating with, the apostolic authority of the popes. Above all, these virtues were shown to come together in the example of Charlemagne. This interpretation of the compilers' priorities does not account for absolutely everything-it is difficult to locate the locust plague of 873 , for example, or the lengthy account of Persian diplomacy in 807 in these categories. Nonetheless, virtually everything that Regino had to say on the primary themes was selected by the epitomists; it looks as if somebody carefully went through the text with these particular categories in mind. It also looks as if this was how at least some people understood the excerpted text in the later twelfth century, since many of the passages concerning papal supremacy and pious kingship were marked as "worthy of memory" in the margins. ${ }^{50}$ The epitomizers were not engaged in a wholesale disruption of Regino's historical vision. The themes identified were already present in the original. The achievement of the Corpus editors was to screen out much of the background noise through the process of selection, turning the treble up to a shrill maximum and fading out the textures that made the original work so complex. By decontextualizing certain elements of Regino's story, the epitomizers made these elements virtually the whole story. The events related by the Chronicle were located, in this new version, in a dimly lit Frankish past where they floated free of textual and historical moorings-and when they looked

\footnotetext{
${ }^{47}$ Regino, Chronicle, 94, s.a. 868.

${ }^{48}$ MacLean, History and Politics, 23-25.

${ }^{49}$ On which see Karl Heidecker, The Divorce of Lothar II: Christian Marriage and Political Power in the Carolingian World, trans. Tanis Guest (Ithaca: Cornell University Press, 2010).

${ }^{50}$ For example: fols. 24r (Rome as "head of all the churches"), 32r (King Boris entering the monastery), and $34 \mathrm{r}$ (the piety and alleged chastity of Charles the Fat). On the marginal notations see above, p. 652.
} 
into that past, what the monks saw was themselves and their own age reflected back at them. In order to understand the environment that gave meaning to this fairground-mirror vision of Carolingian history we must turn to the contemporary political situation.

\section{Durham, Rome, AND Aachen}

The most striking theme of the epitome, namely, the status that should be accorded to papal authority by secular rulers, was a particularly hot topic thanks to the Alexandrine schism, which defined European politics for much of the 1160s. A disputed papal election in 1159 created a schism between two candidates: Alexander III and Victor IV, the latter succeeded in 1164 by Paschal III. The dispute had a profound impact on the relationships between the rulers of the great European kingdoms. While Alexander was backed by the French king Louis VII (1137-80), Victor and Paschal enjoyed the support of Emperor Frederick I Barbarossa, king of Germany and Italy (1152-90), whose long-simmering resentment of Roman authority over the German episcopate escalated in the 1160s into a series of confrontations about papal-imperial relations more generally. ${ }^{51}$ To observers in the north of England, these distant events were made more relevant by the famous dispute between King Henry II (1154-89) and his troublesome archbishop, Thomas Becket, which had an intimate relationship to developments on the Continent. Although the papal schism had placed Frederick and Louis VII more or less consistently on opposite sides, the benefits of distance allowed Henry to take a more opportunistic stance. ${ }^{52}$ However, the spectacular falling out between Henry and Becket in 1163-64 changed everything thanks to the ostentatious support shown to the archbishop by Alexander III. The pope subsequently acted as Becket's main protector and advocate, their alliance made closer after both were forced into exile in France in 1164.

One consequence of these developments was that Henry II was pushed into an alliance with Frederick Barbarossa. The groundwork for their entente was laid in early 1165, when Henry reacted to Alexander's support of Becket by threatening to place the English church in the obedience of Paschal III. ${ }^{53}$ In April of that year Henry met with Rainald of Dassel, Frederick's chancellor, at

\footnotetext{
${ }^{51}$ For introductory discussion see Colin Morris, The Papal Monarchy: The Western Church from 1050 to 1250 (Oxford: Oxford University Press, 1991), 188-97; and Ian S. Robinson, “The Papacy, 1122-1198," in The New Cambridge Medieval History, vol. 4, C.1024-c.1198, pt. 2, ed. David Luscombe and Jonathan Riley-Smith (Cambridge: Cambridge University Press, 2004), 317-83. See further Johannes Laudage, Alexander III. und Friedrich Barbarossa, Forschungen zur Kaiser- und Papstgeschichte des Mittelalters 16 (Vienna: Böhlau, 1997); Benjamin Arnold, “The Western Empire, 1125-1197," in New Cambridge Medieval History, vol. 4, ed. Luscombe and Riley-Smith, 384-421; and Johannes Laudage, Friedrich Barbarossa (1152-1190): Eine Biografie (Regensburg: Pustet, 2009).

${ }^{52}$ Anne Duggan, "Henry II, the English Church and the Papacy, 1154-76," in Henry II: New Interpretations, ed. Christopher Harper-Bill and Nicholas Vincent (Woodbridge: Boydell, 2007), 15483 , esp. $168-72$.

${ }^{53}$ Frank Barlow, Thomas Becket (Berkeley: University of California Press, 1986), 136 and 147; Martin Aurell, The Plantagenet Empire, 1154-1224 (Harlow: Longman, 2007), 240.
} 
Rouen. Rainald then visited Winchester, and a month later English legates were present at an imperial assembly at Würzburg, where sworn denunciations of Alexander III were required from all present. It was also at this time that the two rulers began to discuss family marriages to seal their alliance. ${ }^{54}$ The complex set of relationships shaped by the papal schism and Alexander's poisonous relationship with the emperor was therefore brought to bear on English politics at the very moment when the Durham booklet containing the epitome was being put together.

These circumstances may have held particular interest for the Regino epitomists since one of the chief architects of Henry II's alliance with Frederick Barbarossa was probably none other than the bishop of Durham, Hugh du Puiset (1153-95). This fact is not directly attested in the sources, but it has been taken as likely by historians because of the bishop's closeness to the king and because of his unique family connections. Hugh, who had been born on the Continent, was a nephew of King Stephen and belonged therefore to the comital house of Blois. ${ }^{55}$ This made him a first cousin of the extremely powerful Count Henry the Liberal of Champagne (and Blois), who led a pro-imperial/anti-Alexander party within the French kingdom. ${ }^{56}$ Kinship ties were not necessary determinants of political allegiance, and it is regrettable that the bishop's movements in 1164-65 are obscure; but there is evidence that the most senior members of the Blois family acted together and that Hugh, uniquely among the English episcopate, anticipated Henry II's later position in rejecting Alexander's legitimacy from an early date ${ }^{57}$ It is probable, therefore, that the political implications of the schism were bigger news in Durham than anywhere else in England during the early and middle years of the 1160s, and it would be surprising if these circumstances had not influenced contemporary views of history, such as that expressed in the Regino epitome.

We can, however, go further. That the schism was not merely a talking point in the cathedral community but rather a matter of some urgency is made likely by the fact that, precisely at this time, the monks and bishop of Durham were engaged in a bitter dispute whose course was profoundly affected by these wider political forces. Tensions between community and bishop were more or less

\footnotetext{
${ }^{54}$ Robert Folz, Le souvenir et la légende de Charlemagne dans l'empire germanique medieval (Paris: Les Belles Lettres, 1950), 204; Jens Ahlers, Die Welfen und die englischen Könige, 1165-1235, Quellen und Darstellungen zur Geschichte Niedersachsens 102 (Hildesheim: Lax, 1987), 44-73; Laudage, Alexander III., 156-68; Laudage, Friedrich Barbarossa, 235-37. On relationships between the two rulers see also Karl Leyser, "Frederick Barbarossa, Henry II and the Hand of St James," English Historical Review 90 (1975): 481-506; and Wolfgang Georgi, Friedrich Barbarossa und die auswärtigen Mächte, Europäische Hochschulschriften, 3rd ser., 442 (Bern: Lang, 1990), esp. 117-49 and 248-95.

${ }^{55}$ See Scammell, Hugh du Puiset; and Geoffrey W.S. Barrow, "Hugh du Puiset," Oxford Dictionary of National Biography (Oxford: Oxford University Press, 2004-), s.v.

${ }^{56}$ On Henry the Liberal and his principality see Theodore Evergates, The Aristocracy in the County of Champagne, 1100-1300 (Philadelphia: University of Pennsylvania Press, 2007), 15-24.

${ }^{57}$ Scammell, Hugh du Puiset, 1-12 and 22-30; Yves Sassier, Louis VII (Paris: Fayard, 1991), 296; Duggan, “Henry II,” 168.
} 
endemic after the Benedictine "reform" of 1083, and they typified a type of conflict that was widespread in twelfth-century England. Problems arose particularly when the bishop was a secular rather than monastic figure, as in the episcopate of Ranulf Flambard (1099-1128), under (and against) whom Symeon of Durham had written. This cold war turned on two central issues: the status of the prior (the leader of the monks) in the diocese and the division between the monastic estate and the lands belonging to the bishop. The former issue was nominally resolved in 1147 , when a tribunal specified that the prior was to rank as second in command to the bishop and was formally to outrank the archdeacon, an episcopal officer. ${ }^{58}$ Yet tensions over this matter, which was really about who was to be the effective abbot of the cathedral community and who was to run the diocese when the bishop was absent, by no means evaporated; and conflicting claims over various estates belonging to the Church, although theoretically sorted out in the eleventh century, likewise remained a fraught issue until at least the thirteenth. ${ }^{59}$ Far from resolution, these smoldering embers ignited an intense phase of conflict during the time of Hugh du Puiset. ${ }^{60}$

Hugh was one of the major political players of the later twelfth century and served a series of kings more or less loyally; but despite his Establishment credentials, his holding of the office was not an unwelcome imposition on the Durham monks (who claimed the right to determine episcopal elections). In fact, he was elected in 1153 by the monks, and they fought hard to have him succeed in the face of strident opposition from the archbishop of York. ${ }^{61}$ The honeymoon did not last, however, beyond late 1162, when Prior Thomas confronted Hugh about "certain liberties" enjoyed by the community, in particular relating to its church at Northallerton, and found himself deposed and exiled to the Farne Islands for his trouble. ${ }^{62}$ It seems likely that this crisis had been brewing for some time, and it probably reflects the bishop's gradual assertion of control over Durham's properties in Yorkshire, including Northallerton, which were traditionally reserved for the monks. The prior's last known act before confronting Hugh in 1162 had been to get Alexander III to take the monks into his protection and to confirm their properties and rights as Ranulf Flambard had left them, while the first act of his successor, Germanus, was to secure from the same pope a

\footnotetext{
${ }^{58}$ Aird, St Cuthbert and the Normans, 181-82.

${ }^{59}$ Frank Barlow, Durham Jurisdictional Peculiars (Oxford: Oxford University Press, 1950), 10; Crosby, Bishop and Chapter, 137-38.

${ }^{60}$ For broader analysis of bishop-convent relations see Scammell, Hugh du Puiset, 128-67; and Aird, St Cutbbert and the Normans, 142-83.

${ }^{61}$ Scammell, Hugh du Puiset, 12-21; Aird, St Cuthbert and the Normans, 182. Hugh rewarded the monks by confirming the community's version of their holdings and rights: M.G. Snape, ed., English Episcopal Acta, vol. 24: Durham, 1153-1195 (Oxford: Published for the British Academy by Oxford University Press, 2002), no. 25; Scammell, Hugh du Puiset, 254.

${ }^{62}$ Geoffrey of Coldingham, De statu ecclesiae Dunhelmensis, ed. James Raine, in Historiae Dunelmensis scriptores tres: Gaufridus de Coldingham, Robertus de Graystanes, et Willielmus de Chambre, Publications of the Surtees Society 9 (London: Nichols, 1839), 8. Although Geoffrey is a thirteenth-century source, the charter evidence confirms that Northallerton was a particular point of conflict and establishes the date as 1162: Walther Holtzmann, ed., Papsturkunden in England, vol. 2, Die kirchlichen Archive und Bibliotheken, pt. 2, Abhandlungen der Gesellschaft der Wissenschaften zu Göttingen, Phil.-Hist. Klasse, 3rd ser., 15 (Berlin: Weidmann, 1936), nos. 107 and 111.
}

Speculum 87.3 (July 2012) 
specific confirmation that the monks were the rightful holders of the church at Northallerton, as Hugh du Puiset had himself earlier guaranteed. ${ }^{63}$

It was rare for popes to issue charters dealing with such precise and superficially minor matters as the control of a single dependent church, so it is worth considering what made Northallerton so significant. The estate was originally granted to William of Saint-Calais by King William II in 1091, subsequently seized back by Henry I, and definitively granted to Ranulf Flambard in $1116 .{ }^{64}$ Sometime after that, the same bishop granted the monks its tithe income. ${ }^{65}$ However, a continuation of Symeon's Libellus (possibly composed in the 1160s) reports that William Cumin, a would-be bishop, during a bout of conflict with the monks in the 1140s built a castle at Northallerton and gave it to his nephew. ${ }^{66}$ This was presumably the same castle of which Bishop Hugh had possession in 1154 and which Henry II granted special dispensation for him to keep. ${ }^{67}$ By this point, after a series of invasions, disputed episcopal elections, and a civil war, the estate was clearly subject to multiple and competing potential claims.

Northallerton was worth fighting over in part because of its location. Its strategic value lay in its position at the head of the Vale of York on a major road between York and Durham; it thereby formed a key part in a network of estates established to control the region in the late eleventh century by King William II. ${ }^{68}$ But the estate had also come to hold a significant place in the monks' imaginations. In the Libellus Symeon tells how a punitive raid sent north by William the Conqueror, which had forced the community to flee to Lindisfarne, was seen off at Northallerton by a providential cloud of mist, interpreted as a miracle brokered by St. Cuthbert himself. ${ }^{69}$ This anecdote reveals the value that the community placed on the estate already in the early twelfth century, and by demonstrating the numinous presence there of the monks' patron it articulated their claim to possess it. In the retelling and recopying, stories like this helped make the

\footnotetext{
${ }^{63}$ Thomas: Holtzmann, ed., Papsturkunden, 2/2, no. 107 (October 15, 1162); Scammell, Hugh du Puiset, 169-70 and 172-74; Hilary S. Offler, Durham Episcopal Charters, 1071-1152, Publications of the Surtees Society 179 (Gateshead: Printed for the Society by Northumberland Press, 1968), nos. 24-25; Aird, St Cuthbert and the Normans, 173. Germanus: Holtzmann, ed., Papsturkunden, 2/2, no. 111. No. 119 , issued in 1164, is a general confirmation of the monks' possession of their proprietary churches, without specifically naming Northallerton. Snape, English Episcopal Acta, no. 32, sees Alexander's charter of 1163 as ending the dispute, but the mention of agreement between the parties surely refers to the bishop's earlier confirmations of the monks' rights, which he was now deemed to have broken.

${ }^{64}$ For references see Offler, Durham Episcopal Charters, 83-84; and Aird, St Cuthbert and the Normans, 74.

${ }^{65}$ Offler, Durham Episcopal Charters, no. 14; Aird, St Cuthbert and the Normans, 165 . Hugh confirmed the grant at the start of his pontificate, and this was probably confirmed in turn by Hadrian IV in 1157: Snape, English Episcopal Acta, no. 27; Holtzmann, ed., Papsturkunden, 2/2, no. 94.

${ }^{66}$ Symeon, Libellus 5 (continuation beginning "Tribus dehinc annis") 5, pp. 292-93. On the continuations see Rollason's introduction to his edition of the Libellus, lxvi-lxviii, and Meehan, "Notes."

${ }^{67}$ Geoffrey of Coldingham, De statu, 12; Robert Bartlett, England under the Norman and Angevin Kings, 1075-1225 (Oxford: Oxford University Press, 2000), 279-80.

${ }^{68}$ See Paul Dalton, Conquest, Anarchy and Lordship: Yorkshire, 1066-1154, Cambridge Studies in Medieval Life and Thought, 4th ser. 27 (Cambridge: Cambridge University Press, 1994), 83-85; and Crosby, Bishop and Chapter, 138.

${ }^{69}$ Symeon, Libellus 3.15, pp. 184-85.
}

Speculum 87.3 (July 2012) 
possession of estates like Northallerton central to the very identity of the community.

I will return to Northallerton at the end of this article, but for now it is enough to stress that the threat to this very significant possession, together with the exile of Prior Thomas, was enough to trigger a wholesale resurgence of the historical tensions between the bishop and the community. From the 1160s onwards, under Prior Germanus, the community began to pursue its claims against the bishop through production of a series of forged charters. These ran the gamut of the monks' long-standing grievances, from the status of the prior via the community's role in episcopal elections to the monks' right to control particular estates. Medieval forgeries, it should be remembered, were not necessarily attempts to fabricate but can often be seen as responding to a need to document genuine claims that were contested or undocumented. Nonetheless, while the Durham monks produced a couple of such documents in the earlier twelfth century, the scale and coherence of the campaign they mounted in the late 1160s and early 1170 s are extremely unusual. ${ }^{70}$ Among the earliest of the forgeries, probably concocted in the later 1160s, were charters of Archbishop Thurstan of York and William of Saint-Calais that purported to confirm the monks' claims to (among other places) Northallerton. ${ }^{71}$

The dormant grievances reawakened by the flashpoint of 1162 were deeply felt, and it is worth stressing that one of the main ways the monks articulated this sense of grievance was in the production of texts-and not just charters. A deluxe manuscript put together by the monks around 1188 contains a carefully chosen sequence of historical works designed to remind Bishop Hugh of his priorities and to teach him a few subtle but firm lessons in the art of good management. ${ }^{72}$ Given the timing of its production, the main booklet of the Corpus manuscript must surely be read in conjunction with these more obviously strategic texts. The vision of political order presented by the Durham epitome of Regino had particular bite in this environment because papal authority played a key role in the monks' conception of the rightness of their position. They were assiduous in their acquisition of papal documents. Shortly after acquiring from Alexander III the charters of 1162 and 1163 that, as already discussed, were intended to bolster their complaint against Hugh, representatives of the community were again at the pope's side in Clermont in June 1165, where they received confirmation of a dossier consisting of what was described as a "scriptum autenticum," almost certainly a reference to one of the forged charters of William of SaintCalais. ${ }^{73}$ The monks' annual delegations to the curia at this time were evidently

\footnotetext{
${ }^{70}$ David Bates, "The Forged Charters of William the Conqueror and Bishop William of St Calais," in Anglo-Norman Durham, ed. Rollason et al., 111-24.

${ }^{71}$ Offler, Durham Episcopal Charters, no. 6; Janet E. Burton, ed., English Episcopal Acta, vol. 5, York, 1070-1154 (Oxford: Oxford University Press, 1988), no. 43; Bates, "Forged Charters," $116-$ 17.

${ }^{72}$ Norton, "History, Wisdom and Illumination." This manuscript is now split between two books: Cambridge, Corpus Christi College, MS 66; and Cambridge, Cambridge University Library, MS Ff.I.27.

${ }^{73}$ Holtzmann, ed., Papsturkunden, 2/2, no. 120 (no. 119 shows that the monks had also petitioned Alexander in August 1164); Offler, Durham Episcopal Charters, no. 3a; Bates, "Forged Charters," 114-15.
}

Speculum 87.3 (July 2012) 
prompted by the opening of hostilities with Hugh, and this charter shows how anxious they were to gain papal approval for their case. Indeed, Rome had been a place of direct recourse for the community during its legal struggles with various kings and bishops throughout the previous century. ${ }^{74}$ Yet in the mid-1160s, at the very moment when they were looking with renewed anxiety for papal patronage to bolster their position, Henry II's antipathy toward Thomas Becket and Alexander III made their goals ever more difficult to achieve. This antipathy found formal expression in the Constitutions of Clarendon (1164), which among other things sought to limit the referral of ecclesiastical disputes to the papal curia. ${ }^{75}$

It would be surprising if these practical considerations (the monks' habit of looking to Rome for support in local disputes and the barriers being put in their way by kings and bishops) did not help to generate in the cathedral convent a more ideological or principled conception of papal authority-patterns of behavior can, after all, shape patterns of thought. Such a conception was evident already in the story of the installation of the monks in 1083, which in Symeon's telling was accomplished on the authority of Gregory VII; and it can be seen also in texts of the 1160s like Reginald of Durham's Miracles of St. Cuthbert (1167), which includes several stories about Cuthbert miraculously helping travelers complete the dangerous journey to and from the curia of Alexander III. In one of these the miracle was deemed necessary explicitly because Henry II was preventing the monks in question from pursuing an appeal to the pope. ${ }^{76}$ These ideological positions were not adopted for their own sake but developed as responses to particular political circumstances that put the monks on the defensive. As it reached its greatest intensity, the Becket affair made decisions about political loyalty even more fraught than usual: to show open support for Alexander III was

\footnotetext{
${ }^{74}$ Holtzmann, ed., Papsturkunden, 2/2, nos. 5, 11, 29-31, 51, 82, 94, 107, and 111 (several of which included specific confirmations of their claim to Northallerton); Walther Holtzmann, ed., Papsturkunden in England, vol. 3, Oxford, Cambridge, kleinere Bibliotheken und Nachträge aus London, Abhandlungen der Gesellschaft der Wissenschaften zu Göttingen, Phil.-Hist. Klasse, 3rd ser. 33 (Göttingen: Vandenhoeck \& Ruprecht, 1952), nos. 56, 62, and 92. On the monks and the papacy see Scammell, Hugh du Puiset, 12-21; Alan Young, "The Bishopric of Durham in Stephen's Reign," in Anglo-Norman Durham, ed. Rollason et al., 353-68; and Aird, St Cuthbert and the Normans, 179-82.

${ }^{75}$ The constitutions also endorsed the diocesan authority of archdeacons (thus tacitly undermining the position of monastic priors): see especially chapters $1,3,4,8$, and 12 . For the text see Dorothy Whitelock et al., eds., Councils and Synods, with Other Documents Relating to the English Church, vol. 1, AD 871-1204 (Oxford: Clarendon Press, 1981), 877-83; for a translation see Michael Staunton, The Lives of Thomas Becket (Manchester: Manchester University Press, 2001), 91-96. Hugh du Puiset's approval of the "outrageous royal constitutions" is attested by Geoffrey of Coldingham, $D e$ statu, 9-10.

${ }^{76}$ Symeon, Libellus 4.1-2, pp. 222-29; Reginald of Durham, Libellus de admirandis beati Cuthberti virtutibus 52, 55, and 75, ed. James Raine, Publications of the Surtees Society 1 (London: Nichols, 1835), 108-9, 112-14, and 154-57. On Reginald see Sally Crumplin, "Modernizing St Cuthbert: Reginald of Durham's Miracle Collection," Studies in Church History 41 (2005): 179-91. There is also good evidence for the monks' deployment of canon law texts, such as Pseudo-Isidore, which articulated the legal underpinnings of papal supremacy in ecclesiastical matters: see Mark Philpott, “The 'De iniusta vexacione Willelmi episcopi primi' and Canon Law in Anglo-Norman Durham,” in Anglo-Norman Durham, ed. Rollason et al., 125-37, esp. 131-32; and Young, "Bishopric of Durham," 362-63.
} 
becoming tantamount to a declaration of disloyalty toward Henry II. This was especially the case after 1166, when Alexander made Becket papal legate for England except for the diocese of York, and Becket flexed his muscles by scathingly condemning the Constitutions of Clarendon, particularly those clauses that were intended to restrict communication with Rome, and began excommunicating bishops. ${ }^{77}$ Now, as never before, sides were being openly chosen. The monks of Durham, whose prior may have met the exiled archbishop at the side of Alexander III in the summer of 1165 , found themselves, as a consequence of their dispute with their bishop, firmly on the side of the pope. ${ }^{78}$ The complaints of the monks, while rooted in local diocesan politics, were locked by circumstances into step with wider conflicts involving kings, emperors, and popes. These concentric circles of dispute and allegiance help explain the emphases presented by the epitome of Regino, animating its superficially abstract ruminations on the relationship between popes and kings with an urgent contemporary agenda.

One final element of this context remains to be mentioned. What made an epitomized Frankish history such a potent medium for expressing this kind of argument was that the alliance formed against Alexander III by Henry II and Frederick Barbarossa had an explicitly historical dimension of its own. At a major assembly held by the emperor over Christmas 1165 in the great Carolingian palace of Aachen, the bones of Charlemagne were exhumed from their resting place and raised into a golden casket in the middle of the cathedral. This translation, on December 29, was subsequently endorsed by the pro-imperial pope Paschal III as confirmation that Charlemagne was to be recognized as a saint. ${ }^{79}$ This was not a completely novel procedure. The mid-twelfth century was a golden age of royal canonizations: the shades of Henry II of Germany and Edward the Confessor had been recent beneficiaries (1146 and 1161 respectively), while the Danish prince Cnut would receive the same accolade in short order (1169). What was singular about the ceremony conducted in Aachen was that the main actor was Frederick himself: it was he who personally lifted the great emperor's bones reverently into their new casket. ${ }^{80}$ The stage management of this solemn occasion seems to have articulated, using ceremonial grammar, the direct opposite of the model of imperial authority described in the Regino epitome. Through this act, the emperor sought to take unmediated hold of the Carolingian past, and particularly the semilegendary figure of Charlemagne, as legitimation for the dominance he was asserting in European politics. Frederick and his apologists had advertised Charlemagne as a model for his rule ever since the day he was inaugurated

\footnotetext{
${ }^{77}$ Holtzmann, ed., Papsturkunden, 2/2, no. 121; Barlow, Thomas Becket, 143-66, esp. 147-48.

${ }^{78}$ Holtzmann, ed., Papsturkunden, 2/2, no. 120, was issued for the monks at Clermont on June 8, 1165 , around which time Thomas is known to have been at Alexander's side: Staunton, Lives of Thomas Becket, 139.

${ }^{79}$ Folz, Le souvenir, 203-37; Jürgen Petersohn, "Saint-Denis-Westminster-Aachen: Die KarlsTranslatio von 1165 und ihre Vorbilder," Deutsches Archiv für Erforschung des Mittelalters 31 (1975): 420-54; Laudage, Alexander III., 167-71; H. Müllejans, ed., Karl der Große und sein Schrein in Aachen (Aachen: Einhard, 1988).

${ }^{80}$ Petersohn, "Saint-Denis," 425-26; Jürgen Petersohn, "Kaisertum und Kultakt in der Stauferzeit," in Politik und Heiligenverehrung im Hochmittelalter, ed. Jürgen Petersohn, Vorträge und Forschungen 42 (Sigmaringen: Thorbecke, 1994), 101-46.
}

Speculum 87.3 (July 2012) 
on the throne at Aachen in 1152, and the intensification in the 1160s of this rhetoric of precedent was part of an ideological struggle to dominate not just the pope but also the Capetian king, Louis VII. ${ }^{81}$

Yet Frederick was not the only ruler attempting to bolster his authority through appropriation of Carolingian history. The close links established between Henry II and the emperor in the first half of 1165 make it almost certain that the English king's orchestration of the canonization of Edward the Confessor in 1161 (and his translation at Westminster in 1163) was a direct model for what took place at Aachen. This is confirmed by the main source (a charter) for the elevation of Charlemagne, which states that Frederick acted "at the prompting of Henry." 82 We have some interesting hints that the precedent of the great Frankish emperor was also claimed by the English king as an explicit historical antecedent for his own rule. The poetic chronicle of the events of 1173-74 by Jordan Fantosme includes an explicit comparison between Henry and the great Charles, while a German translation of the Song of Roland commissioned by Henry's daughter Matilda glorifies the old emperor much more than had the original written text..$^{83}$ Across the Channel in Normandy, in 1169 Stephen of Rouen flattered Frederick and Henry by describing them as Charlemagne's successors, denying the same status to Louis and thereby casting him as a usurper. ${ }^{84}$ These are echoes, not direct evidence, but together with Henry's involvement in the canonization they suggest that Henry, and not just Frederick, had consciously embraced the figure of a sanctified and triumphant Charlemagne.

This heightened rhetorical atmosphere was generated by the particular political circumstances prevailing in the two or three years after Christmas 1165, and it is this atmosphere that surely informed the Durham epitomists of Regino. No version of Carolingian history produced in such an environment can have been politically neutral. The events of those years brought the relatively parochial conflict between the Durham monks and their bishop into precise alignment with

\footnotetext{
${ }^{81}$ On Frederick's use of the Charlemagne legend see Leyser, "Hand of St James," 234; Petersohn, "Saint-Denis," 446-51; Ferdinand Opll, Friedrich Barbarossa (Darmstadt: Wissenschaftliche Buchgesellschaft, 1990), 93; Heinz Krieg, Herrscherdarstellung in der Stauferzeit, Vorträge und Forschungen 50 (Sigmaringen: Thorbecke, 2003), 76, 102-3, 281, and 229-30; and Laudage, Friedrich Barbarossa, 38, 87, and 238-40. On Capetian claims to the Carolingian legacy see now Matthew Gabriele, "The Provenance of the Descriptio qualiter Karolus Magnus: Remembering the Carolingians in the Entourage of King Philip I (1060-1108) before the First Crusade," Viator 39/2 (2008): 93117. On the ubiquity of Charlemagne in the historical imagination of post-Carolingian Europe see James Fentress and Chris Wickham, Social Memory (Oxford: Blackwell, 1992), 154-62.

${ }^{82}$ H. Appelt et al., eds., Die Urkunden Friedrichs I., 1158-1167, MGH DD F I, 2 (Hannover: Hahn, 1979), no. 502: "sedula peticione karissimi amici nostri Heinrici illustris regis Anglię inducti."

${ }^{83}$ Dieter Kartschoke, ed., Das Rolandslied des Pfaffen Konrad: Mittelhochdeutsch/Neuhochdeutsch (Stuttgart: Reclam, 1993); Aurell, Plantagenet Empire, 141-43; Wendy Hoofnagle, "Charlemagne's Legacy and Anglo-Norman Imperium in Henry of Huntingdon's 'Historia Anglorum," ' in The Legend of Charlemagne in the Middle Ages: Power, Faith and Crusade, ed. Matthew Gabriele and Jace Stuckey (New York: Palgrave Macmillan, 2008), 77-94, at 82.

${ }^{84}$ Stephen of Rouen, Draco Normannicus, ed. Richard Howlett, in Chronicles of the Reigns of Stephen, Henry II and Richard I, Rolls Series 82 (London: Longman, 1886), 670-73 and 720; Leah Shopkow, History and Community: Norman Historical Writing in the Eleventh and Twelfth Centuries (Washington: Catholic University of America Press, 1997), 112-15; Laudage, Friedrich Barbarossa, $238-40$.
} 
the big issues of European politics. The grievances of the cathedral community resonated with the conflict between Frederick Barbarossa and Alexander III because of Henry II's alliance with the emperor, because of Hugh du Puiset's probable role in brokering that alliance, and because of the implications of the Becket dispute. Canon law, Frankish history, and ideas about the formal hierarchies regulating relationships between kings, churchmen, and popes suddenly became matters of urgency. The epitome of Regino's Chronicle, amplifying some of the themes of the original through careful selection, contains implicit and sometimes epigrammatic ruminations on these matters in its presentation of Charlemagne and his family. Henry II's embrace of the Frankish emperor as a legitimizing model for his own kingship was what gave bite to these historical reflections. Indeed, one of the striking facts about Henry's reign is the relative dearth of contemporary national history written in its first two decades, particularly in Latin. ${ }^{85}$ The ideological battles of these decades were to be fought elsewhere-and the distant past was one such place.

The twelfth century understood history to be a "theatre of moral example," and Henry II was said (by Gerald of Wales) to have been a devotee of its lessons. ${ }^{86}$ The lesson that the monks of Durham would have liked to teach Henry was that the Charlemagne of history was not the Charlemagne that Henry and Frederick thought he was; that the true story of the Frankish past did not legitimize the vision of political order that these two rulers shared, nor did it endorse the stance they were taking toward Alexander III. They had the wrong Charlemagne. The Carolingians had been respectful friends of the papacy and owed their authority to the successors of St. Peter. The "crown of life" was properly acquired through holy patience in adversity and submission to God's purpose, not through worldly achievement and the whimsical decision of another secular ruler-here, the example of Charles the Fat, spelled out in detail by Regino, showed Frederick up. The unprecedented attack on Rome mounted by King Arnulf in 896 was sanctioned, in Regino's telling, by the pope, in whose defense it was undertaken. The contrast with Frederick's sacking of Rome in order to install Paschal in 1167, with Alexander forced to flee, would have been unmistakable. ${ }^{87}$ Alexander, implied the epitomists, should have been treated reverently, as Charlemagne treated Leo III and Hadrian I, as Arnulf treated Formosus: he should have been accorded the status of Nicholas I, "commander of kings and tyrants." Kings should be humble, respectful not just of popes but of Benedictine values, such as those prized by the monks of Durham. And so, ultimately, should bishops. It is surely no accident that the very last entry in the

\footnotetext{
85 John Gillingham, "Events and Opinions: Norman and English Views of Aquitaine, c.1152c.1204," in The World of Eleanor of Aquitaine: Literature and Society in Southern France between the Eleventh and Twelfth Centuries, ed. Marcus Bull and Catherine Léglu (Woodbridge: Boydell, 2005), 57-82, at 60; Nicholas Vincent, "The Strange Case of the Missing Biographies: The Lives of the Plantagenet Kings of England, 1154-1272," in Writing Medieval Biography: Essays in Honour of Frank Barlow, ed. David Bates, Julia Crick, and Sarah Hamilton (Woodbridge: Boydell, 2006), 23757, esp. 241.

${ }^{86}$ Vincent, "Strange Case," 237-39; Richard W. Southern, "Aspects of the European Tradition of Historical Writing, 4: The Sense of the Past," in History and Historians, ed. Bartlett, 66-83.

${ }^{87}$ If, of course, the booklet postdated this event.
}

Speculum 87.3 (July 2012) 
entire epitome is an anecdote about a bishop, a close adviser of a king, who lost his life through greed as he tried to escape a raiding army while burdened with his inestimable wealth..$^{88}$ For the monks of Durham, Henry II and Frederick Barbarossa were no Charlemagnes, and Hugh du Puiset, most certainly, was no William of Saint-Calais.

\section{Arguing With the Corpus Booklet}

So far, my discussion has focused on the epitome of Regino, the first text in the main Corpus booklet, and its relationship to the wider political environment of the mid- to late 1160s. I would now like to use my interpretation of this text as a key to unlock the rationale behind some of the booklet's other major historical works, whose inclusion can be seen as responding at least in part to the same set of circumstances. The best illustration of this is the compilers' marked interest in the Battle of the Standard. This battle (August 22, 1138) saw the defeat of an invading Scottish army under King David I (1124-53) by an English force made up largely of northerners; King Stephen had sent only a small contingent, leaving Archbishop Thurstan of York and other local leaders to rally troops. ${ }^{89}$ The victory was sufficiently glorious to be commemorated in a number of roughly contemporary works, all of which are included in the main booklet: the histories by Richard (fl. 1141) and John (d. before 1209), both priors of Hexham; and the short works on the battle by Aelred of Rievaulx and Serlo. These texts are given some prominence in the compilation. Richard's History, which is unique to this manuscript, is placed second, directly after the material excerpted from Regino of Prüm, and covers in some detail the main events of the years 1135 to 1139.90 John of Hexham's work, also unique to CCCC 139, is placed later to reflect the fact that it acts as a continuation of Symeon's Historia regum. John's work, probably written in the later 1150s or early 1160s, covers the years from 1130 to 1153 and was closely based, for its opening pages, on that of Richard. ${ }^{91}$ It is interesting that in the Corpus manuscript the text is split into two parts to accommodate four shorter works, two of them on the Battle of the Standard.

These texts, particularly the two Hexham histories, have figured prominently in debates over the dating and provenance of the manuscript, but little else has been made of their inclusion. Indeed, Baker was of the opinion that the strange interruption of John of Hexham's Historia regum was conceived "arbitrarily." 92 However, if we accept that the effect of this arrangement was to stress the significance of the Battle of the Standard, then it must have been done quite

\footnotetext{
${ }^{88}$ Regino, Chronicle, 148-49, s.a. 901.

${ }^{89}$ See, for instance, R. Oram, David I: The King Who Made Scotland (Stroud: History, 2008), 13544.

${ }^{90}$ Richard of Hexham, History, ed. Howlett, in Chronicles, 139-78.

${ }^{91}$ John of Hexham, History, ed. Thomas Arnold, in Symeonis monachi opera omnia, 2 vols., Rolls Series 75 (London: Longman, 1882-85), 2:284-332. Both Hexham chronicles are translated by Joseph Stevenson, The Church Historians of England, vol. 4, part 1, The Chronicles of John and Richard of Hexham (London: Seeleys, 1856), 1-58. Serlo's poem is edited by Jan Öberg, Serlon de Wilton: Poèmes latins (Stockholm: Almqvist och Wiksell, 1965), 7-9.

${ }_{92}$ Baker, "Scissors and Paste," 84 and 97.
} 
intentionally. This emphasis is highlighted by the contemporary rubricator of the manuscript, who mentioned the battle explicitly not just in relation to the works by Serlo and Aelred but also in the heading to Richard of Hexham's text, which was in fact concerned with much more than the events of August $1138 .{ }^{93}$ The point at which the flow of John's work was broken clearly underlines the booklet's stress on the battle: the interruption comes immediately after the conclusion of the fighting, with the Scottish stragglers being put to death and the king rewarding the English leaders. The compilers then insert descriptions of some natural phenomena before moving on to the inserted battle texts, finally resuming John's chronicle with the visit to England of the papal legate Alberic in the aftermath of the battle. ${ }^{94}$

The reason for this interest in the events of 1138 is not self-explanatoryafter all, the battle was relatively old news by the time the booklet was put together. The compilers' thought processes perhaps become clearer, however, when we realize that the Battle of the Standard was fought only a couple of miles from Northallerton, control of whose church had sparked off the dispute between the monks and Bishop Hugh in 1162 and which, as we have seen, held an important place in the monks' sense of collective identity. This fact is more than incidental, for it is relentlessly stressed in the manuscript. Aelred mentions that the battle took place "in a broad field near Northallerton," as, in similar terms, does Richard. ${ }^{95}$ The Durham rubricator also stressed the importance of the battle's location, revealing something of what the compilers regarded as significant about it: the title given to Aelred's account explicitly states that it took place near Northallerton. ${ }^{96}$ Above all, we should note that although the eponymous standard bore tokens symbolizing saints associated with the diocese of York, the texts in the manuscript give at least equal credit for the victory to St. Cuthbert. A contemporary drawing of the standard on fol. $135 \mathrm{r}$ in fact depicts it crowned with Cuthbert's cross. ${ }^{97}$ Richard of Hexham, summing up the conflict, says, "The ground on which the said battle was fought was alone the possession of

\footnotetext{
93 "Incipit historia pie memorie prioris Ricardi Haugustaldensis ecclesiae De gestis regis Stephani et de bello standardii." Most of the rubrics are printed by Baker, "Scissors and Paste," 106-7.

${ }^{94}$ John, History, 295-97: the split comes at the end of Arnold's chapter 6, with the resumption at chapter 8. Although it is included in the edition by Arnold, chapter 7, the account of the omens, is clearly a separate text inserted in the manuscript. The same text can be found in the chronicle of John of Worcester: Patrick McGurk, ed., The Chronicle of John of Worcester, vol. 3 (Oxford: Clarendon Press, 1998), 208-11 (last line of 1132, whole entry for 1133). William of Glasgow's poem on the death of Sumerled in The Triumph Tree: Scotland's Earliest Poetry, AD 550-1350, trans. Thomas O. Clancy et al. (Edinburgh: Canongate, 1998), 212-14 is the one text whose inclusion in the booklet is hard to explain, though since it is itself contemporary with the compilation of the booklet, it may have been included for topicality or for comparison with the other battle descriptions.

${ }_{95}$ Aelred, Relatio de Standardo, ed. Howlett, in Chronicles, 182; Aelred of Rievaulx: The Historical Works, trans. Jane P. Freeland, ed. Marsha L. Dutton (Kalamazoo: Cicercian Publications, 2005), 245-69; Richard, History, 162.

96 "Descriptio venerabilis viri Aethelredi abbatis Rievallis de bello inter regem Scotiae et barones Angliae apud Standardum iuxta Alvertoniam": Baker, "Scissors and Paste," 107.

${ }^{97}$ On the vexillum of St. Cuthbert see also Reginald of Durham, Libellus 39, pp. 82-83; and John R.E. Bliese, "Saint Cuthbert and War," Journal of Medieval History 24 (1998): 215-41, esp. 23536.
}

Speculum 87.3 (July 2012) 
St. Cuthbert, the whole surrounding district being owned by others." 98 He then goes on to relate how further ravaging perpetrated by some prominent northern nobles was halted only when they arrived in the "terra sancti Cuthberti" and found themselves too frightened to continue. ${ }^{99}$ John of Hexham deploys a similar argument. ${ }^{100}$ Hexham was not formally part of Durham's jurisdiction but rather an island of York authority in Northumbria. Nonetheless, these texts' respect for St. Cuthbert reflects not only their authors' participation in a general northern form of devotion but also the increasingly formal closeness of the Hexham priory to the cathedral in Durham in the mid-1160s. ${ }^{101}$ Richard's other known work, a history of the church of Hexham from the seventh century to the twelfth, also survives in a Durham manuscript and includes Cuthbert in its list of great bishops of Hexham's past. ${ }^{102}$

These texts are complex narratives, and they had not been written with the primary purpose of justifying the claims of the Durham monks to their interests in Northallerton. However, as their rubrication, organization, and context make clear, that is surely why they were copied into the booklet in the mid- or late 1160s. This group of texts served to underline the community's possession of the disputed property much as had Symeon in the Libellus, pressing past events and miracles into the service of present needs. In effect, the Hexham chroniclers and their Durham editors made Cuthbert responsible for the great victory over the Scots and sought to establish him as the defender of the north as a whole, asserting at the same time the special status of Northallerton within the region. Such a claim was not only a potential criticism of King Stephen, whose minimal involvement is made clear by all the sources, but could also have been deployed as a veiled dig at the local bishop: no bishop of Durham is known to have led troops against the Scots in this period, and Richard of Hexham explicitly makes that point about Bishop Geoffrey's inaction in $1138 .{ }^{103}$ Moreover, Richard mentions that the treaty by which David I was made to retreat was concluded at Durham and that it stipulated specifically that the Scots were to leave the lands of St. Cuthbert alone in the future. ${ }^{104}$ The real hero of the north was not the king, and it was not the bishop-it was none other than the saint whose special patronage defined the identity of the monks of the cathedral community and guaranteed their possessions. ${ }^{105}$

\footnotetext{
${ }^{98}$ Richard, History, 165.

${ }^{99}$ Ibid., 166-67.

${ }^{100}$ John, History, 293.

${ }^{101}$ See above, p. 652.

${ }^{102}$ Norton, "History, Wisdom and Illumination," 65 and 97. The inclusion in the booklet of Symeon's letter to Hugh (ed. Thomas Arnold, Symeonis monachi opera omnia, 1:222-28) probably also relates to these Cuthbertine priorities since its account of the translation of Bede's remains to Durham helped anchor the northern version of English history in Durham itself: Bede and Cuthbert, both monks, were joint guarantors of English greatness in the north.

${ }^{103}$ Richard, History, 157; Aird, St Cuthbert and the Normans, 259-62 and 266.

${ }^{104}$ Richard, History, 178.

${ }^{105}$ It is also worth noting in this context that the earliest of the Durham forgeries to include a specific reference to Northallerton was composed in the name of Archbishop Thurstan of York, who was remembered in these texts as another key leader in 1138: see above, p. 666.
} 
A concern to document claims to threatened property may also be detected in the inclusion of De obsessione Dunelmi et de probitate Ucthredi comitis (Concerning the Siege of Durham and the Probity of Count Uctred), another text that survives uniquely in CCCC 139.106 This work, probably written in the first couple of decades of the twelfth century, is a short but extremely detailed account of various property transfers and the violence associated with them from the late tenth century until, probably, the later eleventh; and it has usually been discussed in the context of debates about aristocratic feud or as a possible source for the high political events of a complex period in northern English history. ${ }^{107}$ Yet from a twelfth-century perspective the significance of the text clearly resides in the land claims it narrates-the author even seems to refer to this theme as the "main story"108_ and these claims must explain why the text was preserved. The story revolves around the status of six estates, which at the beginning belong to the bishop of Durham, but by the end, after a variety of exchanges involving gift, dowry, inheritance, theft, and pious donation, have become subject to multiple claims. ${ }^{109}$

One claimant was the cathedral community, and the text itself can be seen as one of the weapons it wielded in attempting to press that claim. The status of the six estates in the $1160 \mathrm{~s}$ is difficult to establish. However, a case can be made that the convent's control of some of these lands was one of the issues in the monks' dispute with Bishop Hugh. Their location is the most important indication of this: all six lay in Yorkshire, in the area between Northallerton and Darlington, and five of them clustered around the main route between Durham and York. ${ }^{110}$ This strategically important southern outpost of the Durham estate was, as noted above, traditionally controlled by the monks, but Hugh had been gradually encroaching on this arrangement in the years running up to the outbreak of open hostilities in $1162 .{ }^{111}$ Echoes of this dispute can be detected in the documents confected by the community. A forged grant of properties and rights by William of Saint-Calais, based very closely on a passage from Symeon's Libellus, was entered into the Durham Liber vitae some time

${ }^{106}$ De obsessione Dunelmi et de probitate Ucthredi comitis, ed. Arnold, in Symeonis monachi opera omnia, 1:215-20; trans. Christopher J. Morris, Marriage and Murder in Eleventh-Century Northumbria: A Study of "De obsessione Dunelmi," Borthwick Papers 82 (York: Borthwick Institute of Historical Research, 1992), 1-5.

${ }^{107}$ Morris, Marriage and Murder, 5-12, provides a judicious analysis of the date and possible authorship (some have argued for Symeon of Durham). For discussion see Bernard Meehan, "The Siege of Durham, the Battle of Carham and the Cession of Lothian," Scottish Historical Review 55 (1976): 1-19; William E. Kapelle, The Norman Conquest of the North: The Region and Its Transformation, 1000-1135 (London: Croom Helm, 1979); Richard Fletcher, Bloodfeud: Murder and Revenge in Anglo-Saxon England (London: Penguin, 2003); and John G.H. Hudson, "Faide, vengeance et violence en Angleterre (ca 900-1200),” in La vengeance, 400-1200, ed. D. Barthélemy et al. (Rome: École française de Rome, 2006), 341-82, esp. 341-50.

${ }^{108}$ De obsessione 8, p. 219.

${ }^{109}$ Morris, Marriage and Murder, 12-27, discusses the properties and the various claims prosecuted.

${ }^{110}$ Morris, Marriage and Murder, 13, and see 4 for a map.

${ }^{111}$ See above, p. 664.

Speculum 87.3 (July 2012) 
before 1123.112 A later version of this text, extracted from the Liber vitae and reconstituted in charter form, was produced during Hugh du Puiset's episcopate, probably between 1162 and $1165 .{ }^{113}$ This document, almost certainly the "scriptum autenticum" presented by the monks to Alexander III for confirmation in 1165, included in its list of properties two of the six dealt with in De obsessione. ${ }^{114}$ Neither the fabricated charter nor De obsessione was exclusively concerned with these two estates, but the overlap is not insignificant, and it demonstrates that the monks were actively pursuing some of the specific claims recorded in this text at the papal curia at the time of the booklet's compilation. Beyond this, De obsessione's status as a record of the church's landholding more generally made it a valuable potential resource in the disputes of the 1160 s. ${ }^{115}$

Other texts in the booklet pick up on central themes of the Regino epitome. Symeon's Historia regum is a major historical compilation written in nine sections that seek to cover English history from the fifth century to 1129 . This is by far the longest work in the Corpus manuscript and clearly serves as the centerpiece of the main booklet. ${ }^{116}$ The final section of the text is an independent set of annals that run from 1119 to 1129 and reveal a pronounced northern (and indeed Cuthbertine) perspective on European affairs, with a particular interest in the relationship between rulers and popes. The 1119 entry, for example, opens with an account of the succession of Calixtus II, a patron of the Durham monks, and recounts in great detail how he laid down the law on ecclesiastical investiture to the emperor, Henry V. Throughout the text's account of tension between pope and emperor, the side of the former is consistently taken, and papal letters and pronouncements are regularly quoted at length and verbatim, underlining prohibitions of secular involvement in episcopal elections and in church affairs in general. ${ }^{117}$ Henry I of England is shown bending to the pope's will in recognizing as archbishop of York Thurstan, who by the 1160s was remembered as a

${ }^{112}$ Offler, Durham Episcopal Charters, no. 3; Bates, "Forged Charters," 112; Symeon, Libellus 4.2, pp. 224-29; David Rollason and Lynda Rollason, eds., The Durham Liber vitae (London: British Library, 2007).

${ }^{113}$ Offler, Durham Episcopal Charters, no. 3a.

${ }^{114}$ Holtzmann, ed., Papsturkunden, 2/2, no. 120; Bates, "Forged Charters," 114-15. The two properties were Monk Heselden and School Aycliffe: see Offler, Durham Episcopal Charters, 10-11. The latter at least is known to have been controlled by the bishop in 1183: Morris, Marriage and Murder, 16.

115 There may also be a crossover with Richard, History, 166, who mentions attempted attacks on St. Cuthbert's land by Edgar, son of Cospatric, and Robert and Uctred, sons of Meldred. These men may have been related to some of the protagonists of De obsessione and possibly represented the continuation of their claims into the next generation. Some of these men appear in other Durham sources: Offler, Durham Episcopal Charters, 11 and 76.

${ }^{116}$ Symeon, Historia regum, ed. Arnold, in Symeonis monachi opera omnia, 2:1-283. Pending the new edition being prepared by David Rollason and Michael Lapidge, see Blair, "Some Observations"; Antonia Gransden, Historical Writing in England, c.550 to c.1307 (London: Routledge, 1974), 14851; Michael Lapidge, "Byrhtferth of Ramsey and the Early Sections of the 'Historia regum' Attributed to Symeon of Durham,” Anglo-Saxon England 10 (1982): 97-122; Symeon, Libellus, pp. xlviii-1; and Story, Carolingian Connections, 116-33.

${ }^{117}$ Symeon, Historia regum, s.aa. 1119 and 1122, pp. 253-58 and 264-67. 
hero of the Battle of the Standard. ${ }^{118}$ Later, under 1125, a letter of Pope Honorius II is quoted in which it is stated that "the kingdom of England belongs in a special manner to blessed Peter and the Roman Church." 119 These sentiments chimed very clearly with the immediately pre-1119 section of the Historia, which was written in a similar style and with similar themes. Here, the fraught relationship between Archbishop Anselm of Canterbury (1093-1109) and Kings William II and Henry I, under whom the prelate went into exile, was recounted with similar emphases.

Similar concerns are not far from the surface of the two Hexham histories. Richard of Hexham opens his work with the death of Henry I, and he inserts the full text of that king's coronation charter (1100), the very first chapter of which echoes some of the strictures expressed in the papal correspondence of the Historia regum by promising that the ruler will not seek to profit by interfering in ecclesiastical vacancies. ${ }^{120} \mathrm{Next}$, the chronicler endorses the legitimacy of King Stephen by inserting the full text of a letter from Innocent II confirming his status. ${ }^{121}$ Papal authority is further invoked in the aftermath of the Battle of the Standard, with the settlement of disputes between the Scots and the English being credited to Innocent via his legate Alberic. ${ }^{122}$ In the same breath Richard refers to Innocent's rival, the "antipope" Anacletus, as "the first born of Satan." 123 John of Hexham picks up and develops these themes, stressing the pope's role as an admonisher of Kings David and Stephen, reiterating the importance of Alberic in 1138, celebrating the reinstallation of Thurstan with the sanction of Rome, and praising Henry II for delegating authority over all disputes to the local papal legate. ${ }^{124}$

The relentless stress in the last two sections of the Historia regum and in the Hexham chronicles on Roman jurisdiction, and the repetitive citation of papal legislation insisting on the freedom of churches from royal control and exaction, are not in themselves remarkable. They were part of the to-and-fro of the investiture disputes of the late eleventh and early twelfth centuries, which had been brought into the heart of English politics by the conflict between Henry I and Anselm. Yet for readers who copied and read these texts in the midst of the Becket dispute, after the election of Paschal III and during the dispute between Henry, Frederick, and Alexander, surely these themes had a pointed contemporary edge. In the wake of the Constitutions of Clarendon and the consequent furor about the "customs of the realm," Henry I's promise to rid the kingdom of "bad customs" and Innocent II's admonition that Stephen should institute "ancient laws and right customs," as recorded by Richard and John respectively,

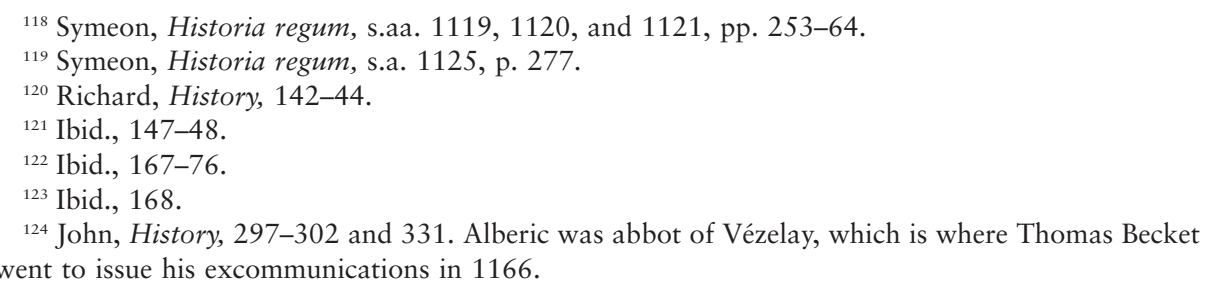


must have been seen as once more urgently relevant. History was repeating: things were different, but the same. Once again the archbishop of Canterbury was in Continental exile, and once again an English king and a German emperor were openly defying the authority of the rightfully chosen pope. ${ }^{125}$ These were certainly not the only themes of the Hexham chronicles, nor of the Historia, but they constituted the loud fanfare with which the latter reached its conclusion: in this work's closing sections, the history of the English culminates in another case study of the principles derived by the epitomists from Regino's Chronicle.

\section{CONCLUSION}

It would be wrong to overstate the coherence of the material selected by the Durham monks in the booklet that became the second section of CCCC 139. Collections of this kind, as already mentioned, did not necessarily respond to a single stimulus, and the preservation of historical texts in this manner most likely met more than one need. ${ }^{126}$ The texts themselves had many more themes and concerns than those emphasized here: this was not an airtight political manifesto in the sense that we might define such a thing today. Much remains to be said about the booklet and about its absorption into a codex whose overall shape may have responded to quite different stimuli. ${ }^{127}$

Yet the common themes and shared details running through many of the texts under discussion should not be written off as coincidence. History writing in this period was a collaborative enterprise, not just on the level of communities like those of the cathedral monks, but also in a more general sense. The major northern monastic houses were connected by a shared manuscript culture that involved them in regular exchanges of personnel and books. The writing and the collection of history in this environment were partly expressive of a corporate northern English identity, and the cathedral community of Durham sat at the center of a complex web of intellectual connections that helped articulate that identity. ${ }^{128}$ The Durham monks were likely part of an even broader network of contacts that gave them access to booklets of historical work in progress from

${ }^{125}$ On the earlier events see Karl J. Leyser, "England and the Empire in the Early Twelfth Century," in Karl J. Leyser, Medieval Germany and Its Neighbours, 900-1250 (London: Hambledon, 1982), 191-214.

${ }^{126}$ Pohl, "History in Fragments," esp. 346-47 and 353, underlines the dangers of attempting to explain away apparently incoherent elements of such collections.

${ }^{127}$ The compilers' interest in the status of the Scottish church, untouched in this article, is particularly noticeable and may be connected to Alexander III's approval of the consecration of a bishop of St Andrews in 1165 without reference to the English archbishop: see, for example, Richard Sharpe, "Symeon as Pamphleteer," in Symeon, ed. Rollason, 214-29; and Dauvit Broun, Scottish Independence and the Idea of Britain: From the Picts to Alexander III (Edinburgh: Edinburgh University Press, 2007), 112.

${ }^{128}$ Meehan, "Durham Twelfth-Century Manuscripts"; Norton, "History, Wisdom and Illumination," 101; Robert Bartlett, "Cults of Irish, Scottish and Welsh Saints in Twelfth-Century England," in Britain and Ireland, 900-1300: Insular Responses to Medieval European Change, ed. Brendan Smith (Cambridge: Cambridge University Press, 1999), 67-86; Lawrence-Mathers, Manuscripts; Lawrence-Mathers, "William of Newburgh." 
further afield, like the snippet of John of Worcester's chronicle found in the booklet. ${ }^{129}$ But this encyclopedic approach to history need not have been neutral. Compilation was itself an act akin to authorship: this had always been true but by this period was coming to be recognized explicitly. ${ }^{130}$ Sequencing and rearranging created meaning. Texts written for one purpose could, through the act of compilation, therefore be turned to others. So it must have been with the Corpus booklet, whose editorial rationale was intimately connected to the circumstances of the later 1160s, in which the local grievances of the monks of Durham resonated precisely with the great dramas of European politics thanks to the alliance formed by Henry II and Frederick Barbarossa against Alexander III and Thomas Becket.

Still, there is no reason to believe that this compilation ever reached, or was intended to reach, any of the main players in those dramas. The manuscript is carefully written but not, by comparison with other Durham products, deluxe-it does not look as if it was designed for formal presentation, even to a local player like Bishop Hugh. ${ }^{131}$ The complaints of the monks are unlikely to have cost Henry II much sleep, far less Frederick I, and it is entirely possible that the booklet had no external audience or practical purpose; we can see it simply as an artifact of the community's disenchantment, affirming the monks' sense of themselves as a group that had been subjected to injustice and persecution. The depth with which that injustice was felt can be glimpsed in another Durham manuscript containing a list of bishops dating to c.1166, in which the name of Hugh du Puiset was erased with such force that a hole was made in the parchment. ${ }^{132}$

Such a conclusion does not diminish the interest of the compilation, since it illuminates for us a local response to dramatic political events even if it had no immediate effect upon them. It shows how the outlooks of local elites could be framed by distant events and how the deeds of kings and emperors could interlock with politics on much more local stages. Relative small fry like the monks of Durham had to shout to get themselves heard in royal and papal courts, and aligning their messages with narratives about rulers and popes was an important strategy to gain leverage. This kind of collection can bear indirect witness to the ways in which the world of high politics was actively internalized by local elites. The power of rulers was not just something that they felt as an imposition from above; it was also something they clamored for and competed to appropriate as a frame for their own views of the world.

Moreover, even if the Corpus booklet was not intended to have an audience external to the community, the people whose consciousness it helped define were

\footnotetext{
129 See Martin Brett, "John of Worcester and His Contemporaries," in The Writing of History in the Middle Ages: Essays Presented to Richard William Southern, ed. R.H.C. Davis and J.M. WallaceHadrill (Oxford: Clarendon Press, 1981), 101-26; and Southern, "Sense of the Past," 71-72.

${ }^{130}$ Malcolm B. Parkes, "The Influence of the Concepts of Ordinatio and Compilatio on the Development of the Book," in Malcolm B. Parkes, Scribes, Scripts and Readers: Studies in the Communication, Presentation and Dissemination of Medieval Texts (London: Hambledon, 1991), $35-70$.

${ }^{131}$ Norton, "History, Wisdom and Illumination," 62.

${ }^{132}$ Durham, Dean and Chapter Library, MS B II 35: Norton, "History, Wisdom and Illumination," 100 .
}

Speculum 87.3 (July 2012) 
nonetheless actively involved in pursuing their complaints through political intrigue. With this in mind, we might think about the booklet not just as a source of reassurance, a self-righteous documenting of grievances, but also as a kind of storehouse of potentially useful arguments. Some of the weapons in this arsenal were ideological, describing the correct relationship between popes and rulers in ways that would have played to Alexander III's own sense of injustice, while others related to specific issues, such as the status of Northallerton. All used history to argue for a particular view of the right order of the world and, implicitly, for the bishop, king, and emperor as having set themselves against that order. Legal arguments were not pursued exclusively through legal genres: in disputes of this sort, historical and legal modes of argument overlapped. ${ }^{133}$ Even the community's forged charters crossed genre boundaries: the "scriptum autenticum" setting out the community's claims and presented to the pope in 1165, for example, started life as a passage in a historical text (Symeon's Libellus) and was then adapted for entry into the liturgical Liber vitae before being redrawn as a formal charter. ${ }^{134}$ De obsessione, similarly, underlines how even claims to specific properties could depend on highly developed and complex historical narratives, not simply on the perceived authority of one legal document over another. Such narratives, which cumulatively served to link the minutiae of Northumbrian politics to the political hierarchies of Rome and the empire, may in the end have helped the monks win influence at the papal court where they prosecuted their claims. Prior Germanus is known to have visited Alexander III at least once during the pope's second exile in Benevento in the period 1167-69, when once again the monks received confirmation of their rights. ${ }^{135}$ Whatever the nature of the arguments aired on this occasion, it may not be pure coincidence that papal missives issued in the wake of Germanus's visit begin to castigate Bishop Hugh more directly and personally than hitherto, warning him against illegal encroachments on various northern monasteries and chastising him for forcing monastic leaders into secular courts. ${ }^{136}$

Whether or not the booklet helped the monks in their dealings at the exiled curia, it is clear that it did not have a lasting impact in the scriptorium where it was produced. Many of the texts it contains were never copied there again (as far as we know) - and not just Regino's Chronicle but also those with more

${ }^{133}$ Pohl, “History in Fragments," 355.

${ }^{134}$ Bates, "Forged Charters," 123.

${ }^{135}$ Holtzmann, ed., Papsturkunden, 2/2, no. 124.

${ }^{136}$ See, for example, Walther Holtzmann, ed., Papsturkunden in England, vol. 1, Bibliotheken und Archive in London, Abhandlungen der Gesellschaft der Wissenschaften zu Göttingen, Phil.-Hist. Klasse, n.s. 25 (Berlin: Weidmann, 1930), nos. 106-7; and Holtzmann, ed., Papsturkunden, 3, nos. 160, 167, 173-76, and 178-80. The inclusion in the booklet of Aelred's account of the nun of Watton makes sense in this context, as it revived memories of a scandal in the Gilbertine monastic order, which Alexander had charged Hugh du Puiset with sorting out but which, in a letter of 1167-69, he complained had not been resolved: Holtzmann, ed., Papsturkunden, 1, no. 103. On the text see Giles Constable, "Aelred of Rievaulx and the Nun of Watton: An Episode in the Early History of the Gilbertine Order," in Medieval Women, ed. Derek Baker, Studies in Church History, Subsidia 1 (Oxford: Published for the Ecclesiastical History Society by Basil Blackwell, 1978), 205-26; and Brian Golding, Gilbert of Sempringham and the Gilbertine Order (Oxford: Clarendon Press, 1995), 3338.

Speculum 87.3 (July 2012) 
obvious local interest, like the Historia regum and De obsessione. Instead, the booklet found itself bound with others into the manuscript now known as CCCC 139 and was shipped off to the relatively insignificant library at Sawley. ${ }^{137} \mathrm{Al}-$ though the reasons for this transfer are obscure, it can be suggested that the limited shelf life of the compilation at Durham was connected to the unraveling of the political context within which it had been generated. Reconciliation between Frederick and Alexander had to wait another few years, until 1177, but the rationale for an alliance between the emperor and the king of England was removed long before then. ${ }^{138}$ The murder of Thomas Becket in 1170 effectively ended the phase of hot conflict that had tied the Durham dispute into the wider political tension associated with the papal schism. The archbishop's death paved the way for a reconciliation between Henry II and Alexander III, which was sealed by a compromise brokered at Rome in 1171, with representatives of Bishop Hugh present. ${ }^{139}$ The world moved on as the rebellion of Henry the Younger, which placed Hugh du Puiset and the king on opposite sides, reset the English political agenda.

In 1172 Thomas Becket was recognized as a saint, and his feast day was established on the anniversary of his martyrdom, December 29. This was the very day on which, only a few years earlier, Charlemagne's body had been translated and which had thus been earmarked as the festival of St. Charles. Thus was the sanctity of the wronged archbishop allowed to efface, as part of an uneasy compromise between the pope and his former enemies, that of the emperor whose specter had been resurrected in the course of their prior rivalry. History, if not rewritten, was at least reprioritized. In this changed political environment, the relevance of the materials gathered in the booklet may have seemed diminished, though the monks continued to make their case by producing charters and other texts until, nearing death, Hugh made a final and full restitution to the community. Yet even that act of deathbed magnanimity was carried out with a historical perspective in view, for the bishop's act was consciously modeled on the similar bequest made by his predecessor Ranulf Flambard. ${ }^{140}$ From beginning to end, the struggle between Hugh and the monks had relied on the production of documents and on energetic politicking but, above all, on arguments about the shifting shape of history. Perhaps, had they been in a position to know of it, the protagonists would have recognized the truth in William Faulkner's famous dictum: "The past is never dead. It's not even past." 141

\footnotetext{
${ }^{137}$ The founding family of Sawley had personal links to Bishop Hugh: Scammell, Hugh du Puiset, 226 n. 5, 267, and 289.

${ }^{138}$ Laudage, Alexander III., 187-238.

${ }^{139}$ Barlow, Thomas Becket, 255-56.

${ }^{140}$ Snape, English Episcopal Acta, nos. 42-44.

${ }^{141}$ William Faulkner, Requiem for a Nun (New York: Random House, 1951), 92.
}

Simon MacLean is a Reader in History at the University of St Andrews (e-mail: sm89@standrews.ac.uk).

Speculum 87.3 (July 2012) 
Appendix

\begin{tabular}{|c|c|c|}
\hline Text & Folios & Description \\
\hline 1. & $1 \mathrm{r}-16 \mathrm{v}$ & $\begin{array}{l}\text { History in Every Form ('Historia omnimoda'), from the Creation to } \\
\text { King David, plus list of popes from St. Peter to Calixtus II (1119- } \\
\text { 24). }\end{array}$ \\
\hline 2. & $17 \mathrm{r}-35 \mathrm{v}$ & Extracts from Regino of Prüm, Chronicle. \\
\hline 3. & $36 r-46 r$ & $\begin{array}{l}\text { Richard of Hexham, History of the Church at Hexham, The Deeds } \\
\text { of King Stephen, and The Battle of the Standard (from 1135-39). }\end{array}$ \\
\hline 4. & $46 r-48 v$ & $\begin{array}{l}\text { Chronicle from Adam to the Emperor Henry } V \text { (which is little more } \\
\text { than a list of rulers). }\end{array}$ \\
\hline 5. & $48 v-49 v$ & $\begin{array}{l}\text { Symeon of Durham, Letter to Hugh, Dean of York, about the } \\
\text { Archbishops of York. }\end{array}$ \\
\hline 6. & $50 \mathrm{r}-51 \mathrm{v}$ & $\begin{array}{l}\text { The Siege of Durham and the Probity of Earl Uhtred and of the Earls } \\
\text { who Succeeded Him. }\end{array}$ \\
\hline 7. & $52 \mathrm{r}-129 \mathrm{r}$ & istory of the Kings ('Historia Regum'). \\
\hline 8a. & $129 \mathrm{v}$ & $\begin{array}{l}\text { John of Hexham's continuation of the Historia Regum (from 1130- } \\
53 \text { ). Texts } 9 \text { to } 12 \text { are inserted into the middle of this work. }\end{array}$ \\
\hline 9. & $132 \mathrm{r}-\mathrm{v}$ & $\begin{array}{l}\text { Description of omens foretelling the death of King Henry I in } 1135 \\
\text { (also found in John of Worcester's Chronicle). }\end{array}$ \\
\hline 10. & $132 v-133 r$ & $\begin{array}{l}\text { Serlo's poem, addressed to Ralph, abbot of Louth Park, about the } \\
\text { Battle of the Standard (in 1138). }\end{array}$ \\
\hline 11. & $133 r-v$ & $\begin{array}{l}\text { William of Glasgow, Poem about the Death of Somerled at the bat- } \\
\text { tle of Renfrew in } 1164 \text {. }\end{array}$ \\
\hline 12. & $133 v-138 \mathrm{r}$ & $\begin{array}{l}\text { Aelred of Rievaulx, account of The Battle of the Standard (in 1138). } \\
\text { This includes, on 135r, a contemporary drawing of the epony- } \\
\text { mous standard. }\end{array}$ \\
\hline b. & & continuation of the Historia Regum (resumed). \\
\hline & & \\
\hline 4. & & Thitby, History of the Foundation of the Abbey of St \\
\hline 15. & & How Fountains Abbey Assumed its Foundation. \\
\hline 16. & & $\begin{array}{l}\text { Thurstan, archbishop of York, Letter about the Departure of the } \\
\text { Monks of Fountains from the Monastery of St. Mary in York. }\end{array}$ \\
\hline 17. & $158 \mathrm{r}-160 \mathrm{r}$ & $\begin{array}{l}\text { Excerpt from William of Malmesbury, Deeds of the Kings of the } \\
\text { English, ii.167-70, about Gerbert of Reims and his manner of life. }\end{array}$ \\
\hline 18. & $160 \mathrm{r}-161 \mathrm{r}$ & $\begin{array}{l}\text { Excerpt from William of Malmesbury, Deeds of the Kings, ii.111, } \\
\text { concerning Charles the Fat's vision about the future of the empire. }\end{array}$ \\
\hline 19. & $161 \mathrm{r}$ & $\begin{array}{l}\text { Excerpt from William of Malmesbury, Deeds of the Kings, iii. } 268 \text {, } \\
\text { about Archbishop Maurilius of Rouen's vision of the last judg- } \\
\text { ment. }\end{array}$ \\
\hline 20. & $161 \mathrm{r}-\mathrm{v}$ & $\begin{array}{l}\text { Excerpt from William of Malmesbury, Deeds of the Kings, ii.205, } \\
\text { about an engagement ring that was claimed by a bronze statue. }\end{array}$ \\
\hline 21. & $162 \mathrm{r}-164 \mathrm{v}$ & $\begin{array}{l}\text { A story about the wife of Ernulf (translated excerpt from Geoffrey } \\
\text { Gaimar's History of the English). }\end{array}$ \\
\hline 22. & $165 \mathrm{r}-\mathrm{v}$ & $\begin{array}{l}\text { Why the Church of York Ought not to Have Jurisdiction over the } \\
\text { Scots. }\end{array}$ \\
\hline 23. & & The Vision of a Certain Cleric about the Glory of King Malcolm. \\
\hline 24. & $166 \mathrm{v}$ & $\begin{array}{l}\text { Nennius, Eulogy (preface to his chronicle). Fol. 166r contains a quo- } \\
\text { tation from Aelred's Battle of the Standard in a fourteenth-century } \\
\text { hand. }\end{array}$ \\
\hline 25. & & 'Nennius', History of the Britons ('Historia Brittonum'). \\
\hline 26. & & Caradog of Llancarfan, Life of St Gildas. \\
\hline
\end{tabular}

